\title{
A 10 year record of black carbon and dust from a Mera Peak ice core (Nepal): variability and potential impact on melting of Himalayan glaciers
}

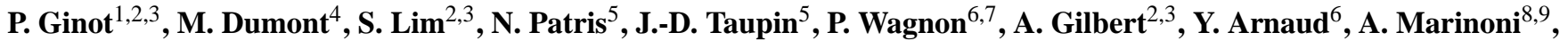 \\ P. Bonasoni ${ }^{8,9}$, and P. Laj ${ }^{2,3}$ \\ ${ }^{1}$ IRD/Univ. Grenoble Alpes/CNRS/Univ.Savoie/INPG/IFSTTAR/CNRM, Observatoire des Sciences de l'Univers de \\ Grenoble (OSUG), UMS222, Grenoble, 38041, France \\ ${ }^{2}$ Univ. Grenoble Alpes, Laboratoire de Glaciologie et Géophysique de l'Environnement (LGGE), UMR5183, \\ Grenoble, 38041, France \\ ${ }^{3}$ CNRS, Laboratoire de Glaciologie et Géophysique de l'Environnement (LGGE), UMR5183, Grenoble, 38041, France \\ ${ }^{4}$ Météo France/CNRS, Centre d'Etude de la Neige (CEN) CNRM-GAME, UMR3589, 38041, Grenoble, France \\ ${ }^{5}$ IRD/CNRS/UM1/UM2, HydroSciences Montpellier (HSM), UMR5569, Montpellier, 34095, France \\ ${ }^{6}$ IRD/UGA/CNRS/INPG, Laboratoire d'étude des Transferts en Hydrologie et Environnement (LTHE), UMR5564, \\ Grenoble 38041, France \\ ${ }^{7}$ ICIMOD, GPO Box 3226, Kathmandu, Nepal \\ ${ }^{8} \mathrm{CNR}$ - Institute for Atmospheric Sciences and Climate, Bologna, Italy \\ ${ }^{9}$ EvK2CNR, Bergamo, 24126, Italy \\ Correspondence to: P. Ginot (patrick.ginot@ird.fr)
}

Received: 4 November 2013 - Published in The Cryosphere Discuss.: 13 December 2013

Revised: 2 July 2014 - Accepted: 4 July 2014 - Published: 14 August 2014

\begin{abstract}
A shallow ice core was extracted at the summit of Mera Peak at $6376 \mathrm{~m}$ a.s.l. in the southern flank of the Nepalese Himalaya range. From this core, we reconstructed the seasonal deposition fluxes of dust and refractory black carbon (rBC) since 1999. This archive presents well preserved seasonal cycles based on a monsoonal precipitation pattern. According to the seasonal precipitation regime in which $80 \%$ of annual precipitation falls between June and September, we estimated changes in the concentrations of these aerosols in surface snow. The analyses revealed that mass fluxes are a few orders of magnitude higher for dust $\left(10.4 \pm 2.8 \mathrm{~g} \mathrm{~m}^{-2} \mathrm{yr}^{-1}\right)$ than for $\mathrm{rBC}$ $\left(7.9 \pm 2.8 \mathrm{mg} \mathrm{m}^{-2} \mathrm{yr}^{-1}\right)$. The relative lack of seasonality in the dust record may reflect a high background level of dust inputs, whether from local or regional sources. Over the 10-year record, no deposition flux trends were detected for any of the species of interest. The data were then used to simulate changes in the surface snow albedo over time and the potential melting caused by these impurities. Mean
\end{abstract}

potential melting caused by dust and $\mathrm{rBC}$ combined was $713 \mathrm{~kg} \mathrm{~m}^{-2} \mathrm{yr}^{-1}$, and for $\mathrm{rBC}$ alone, $342 \mathrm{~kg} \mathrm{~m}^{-2} \mathrm{yr}^{-1}$ for rBC under certain assumptions. Compared to the melting rate measured using the mass and energy balance at $5360 \mathrm{~m}$ a.s.1. on Mera Glacier between November 2009 and October 2010, i.e. $3000 \mathrm{~kg} \mathrm{~m}^{-2} \mathrm{yr}^{-1}$ and $3690 \mathrm{~kg} \mathrm{~m}^{-2} \mathrm{yr}^{-1}$ respectively, the impact of $\mathrm{rBC}$ represents less than $16 \%$ of annual potential melting while the contribution of dust and $\mathrm{rBC}$ combined to surface melting represents a maximum of $26 \%$. Over the 10 year period, $\mathrm{rBC}$ variability in the ice core signal primarily reflected variability of the monsoon signal rather than variations in the intensity of emissions.

\section{Introduction}

Emissions of long-lived greenhouse gases, short-lived reactive trace gases and particles from natural and anthropogenic sources strongly affect atmospheric composition and 
impact climate, air quality and, indirectly, the evolution of the cryosphere. Quantifying emissions is one of the major challenges for the development of air quality and climate policies (Fowler et al., 2009; Isaksen et al., 2009) and quantification should account for different changes in human-related emissions and natural emissions over time as well as changes in their geographical distribution. Major uncertainties in past and current global inventories of anthropogenic and natural emissions limit the establishment of a reliable framework of emission inventories that is required for realistic emission scenarios. This is especially true for the Indian subcontinent where reliable estimates of past and current emissions are crucially lacking. India is one of the two largest anthropogenic aerosol generating countries in the world ( $\mathrm{Lu}$ et al., 2011). In the past decade, India has been identified as a hot spot in terms of high aerosol optical depth (AOD) observed from space (Prasad and Singh, 2007) with components such as sulfate, organic carbon (OC) or black carbon (BC) playing a very active role. India on its own contributes 10 to $20 \%$ of all current aerosol emissions worldwide (Bond et al., 2007) and has therefore received the greatest attention from compilers of emission inventories.

Recent works performed as part of the "atmospheric brown cloud" and the "SHARE" projects (http://www. evk2cnr.org) indicated that the south-facing side of the Himalayas is particularly affected by emissions from the IndoGangetic plains (Bonasoni et al., 2010). Unique atmospheric observations performed at the global GAW (Global Atmosphere Watch) site of the Nepal Climate Observatory Pyramid (NCO-P) facility located at 5079 ma.s.l. in the southern foothills of Mt. Everest (Bonasoni et al., 2010), documented the efficient transport of short-lived climate pollutants (SLCPs) to high altitudes for the first time. Continuous observations over a period of more than 7 years revealed very high concentrations of SLCPs, and in particular black carbon (Marinoni et al., 2010) and ozone (Cristofanelli et al., 2010) especially in the pre-monsoon season. The presence of light absorbing material affects the radiative balance of the atmosphere at both local (Marcq et al., 2010) and regional scales. Source areas of aerosols for the high Himalaya have been clearly identified by (Cristofanelli et al., 2010) and are located in the Indo-Gangetic plains for most of the year. The origin of aerosol species is likely linked to biofuel combustion (Decesari et al., 2010). Desert dust events are also regularly observed at NCO-P, either mixed with anthropogenic pollution from Pakistan and/or directly from the Gobi desert (Bonasoni et al., 2010). Black carbon and dust are efficiently scavenged to the snow/ice surface by dry and wet deposition (Yasunari et al., 2010, 2013; Nair et al., 2013; Ménégoz et al., 2014); these impurities can reduce surface albedo, especially in visible wavelengths, thereby increasing heating and accelerating melting of both ice and snow (e.g. Xu et al., 2009).

Ice cores contain information about past temperatures, precipitation and past deposits of many important species, both short-lived (reactive gases, particulate matter and semi- volatile species) and long-lived $\left(\mathrm{CO}_{2}\right.$ and other greenhouse gases) and have been used to provide independent records of past aerosol load and composition, for example by (Preunkert and Legrand, 2013) for Europe. For the Himalayas, most studies were performed over the Tibetan plateau (i.e. Thompson et al., 1989, 1990, 2000) where the impact of emissions from the Indo-Gangetic plains is reduced because of the dominant westerlies. The southern margin of the Himalayan range is influenced by the seasonal alternation of the westerlies and the Indian monsoon: ice cores extracted from the Mount Everest East Rongbuk glacier $\left(28^{\circ} \mathrm{N}, 87^{\circ} \mathrm{E}\right)$ have used this alternation for example, to determine seasonal cycles even though this glacier is situated on the northern flank of the Himalaya range. The East Rongbuk site has provided a wide range of climatic and environmental records including chemistry and isotopes (Kang et al., 2002; Kaspari et al., 2009; Zhang et al., 2009; Lee et al., 2011), dust (Xu et al., 2010) and the first profile of BC (Ming et al., 2008; Kaspari et al., 2011; Jenkins et al., 2013). The southern flank of the Himalaya range, where the Mera Glacier drilling site is located, is more influenced by monsoon and by southern pollution events than the Rongbuk site.

Radiative forcings of BC in snow and associated enhanced melting have attracted the attention of the scientific community in recent years. Several experimental and modelling studies came to the conclusion that this impact is measurable in Himalayan regions (Ménégoz et al., 2014; Flanner et al., 2012; Sterle et al., 2013; Ming et al., 2009). For example, the atmospheric concentration of BC at NCO-P station was converted into possible changes in albedo by (Yasunari et al., 2010), who concluded that BC deposition may increase glacier water runoff by between 70 and $204 \mathrm{~mm}$ annually. However, the effective impact of increased $\mathrm{BC}$ deposition flux in terms of glacier melting is still highly uncertain. While some studies using simulated snow/ice cover from aerosol emission inventories attributed the decline in the simulated Himalayan snow/ice cover for the 1990-2000 period to increased BC emissions from India (Menon et al., 2010), a recent study by Bond et al. (2013) pointed to very large uncertainties associated with such studies.

Part of this uncertainty is linked to the lack of observations for the Himalayan region, from glacier mass balance to atmospheric composition data at high altitudes, i.e. over $6000 \mathrm{~m}$ a.s.l., where glaciers are covered with snow all year round. In order to study a site mainly influenced by the Indian monsoon, we selected a site on the southern slope of the Himalayas. Here, we present the first results from an ice core extracted from Mera Glacier $\left(6376 \mathrm{~m}\right.$ a.s.1., $27^{\circ} 43^{\prime} \mathrm{N}$, $86^{\circ} 52^{\prime} \mathrm{E}$ ) in Nepal. Together with radiation modelling, we investigated the impact of refractory black carbon $(\mathrm{rBC})$ and dust on seasonal changes in surface albedo and the melting it may have caused over the last decade. 


\section{Site description and experimental methods}

\subsection{Local climatology}

The site is located about $30 \mathrm{~km}$ south of NCO-P, a GAW site that has undergone continuous observations of meteorological parameters and atmospheric composition since March 2006. The meteorological characteristics and air mass circulation that affect NCO-P and the Mera Glacier drilling site are well described in Bonasoni et al. (2010); and in agreement with the local weather regime, we define the seasons as pre-monsoon from March to May, monsoon from June to September, post-monsoon from October to November and winter from November to January. Large-scale Asian monsoon circulation and the local mountain wind system control the atmospheric conditions in Himalayan high-altitude valleys, where $80 \%$ of the annual precipitation is concentrated between June and September (Wagnon et al., 2013; Bonasoni et al., 2010) and is influenced by the summer monsoon (Bonasoni et al., 2010; Ueno et al., 2008; Bookhagen and Burbank, 2006). Hence, Mera Glacier is a summer accumulation type glacier with peak accumulation and ablation occurring simultaneously. At NCO-P, temperatures are highest from June to August. Large scale circulation affecting the Himalayan southern slopes can be described as a balance between eastward travelling disturbances during the cold season (October to May), and monsoon depressions from the northern Gulf of Bengal during the rest of the year. The synoptic origins of the air masses reaching this region are related to these circulation patterns. During the monsoon, $96 \%$ of the air masses are regional or originate from the Gulf of Bengal, whereas during winter (December to March) and post monsoon (October to November), the westerlies favour transport from northwestern India, Pakistan and the Middle East (Bonasoni et al., 2010; Barros and Lang, 2003). During the pre-monsoon period (April to May), high concentrations of aerosols have been reported by atmospheric observations and linked to the direct transport of brown cloud pollutants to the Himalayas (Hindman and Upadhyay, 2002; Bonasoni et al., 2010). The concentration of particles in the atmosphere measured at NCO-P showed two maxima during the pre- and post-monsoon seasons, while the minima during monsoon corresponded to the efficient washout of particles by rain before they reached the Himalayas (Sellegri et al., 2010).

\subsection{Field campaign}

Only a few glaciers on the southern slopes of the Himalayas with the expected characteristics in terms of temperature, geometry, accumulation rates, access and safety are suitable for ice core investigations. One site was identified in the accumulation zone of Mera Glacier (6376 m a.s.1., 27 $43^{\prime} \mathrm{N}$, $86^{\circ} 52^{\prime} \mathrm{E}$ ) in Nepal, in the Himalayan south range, a glacier that has been studied since 2007 in the framework of SOERE (Systèmes d'Observation et d'Expérimentation au long terme

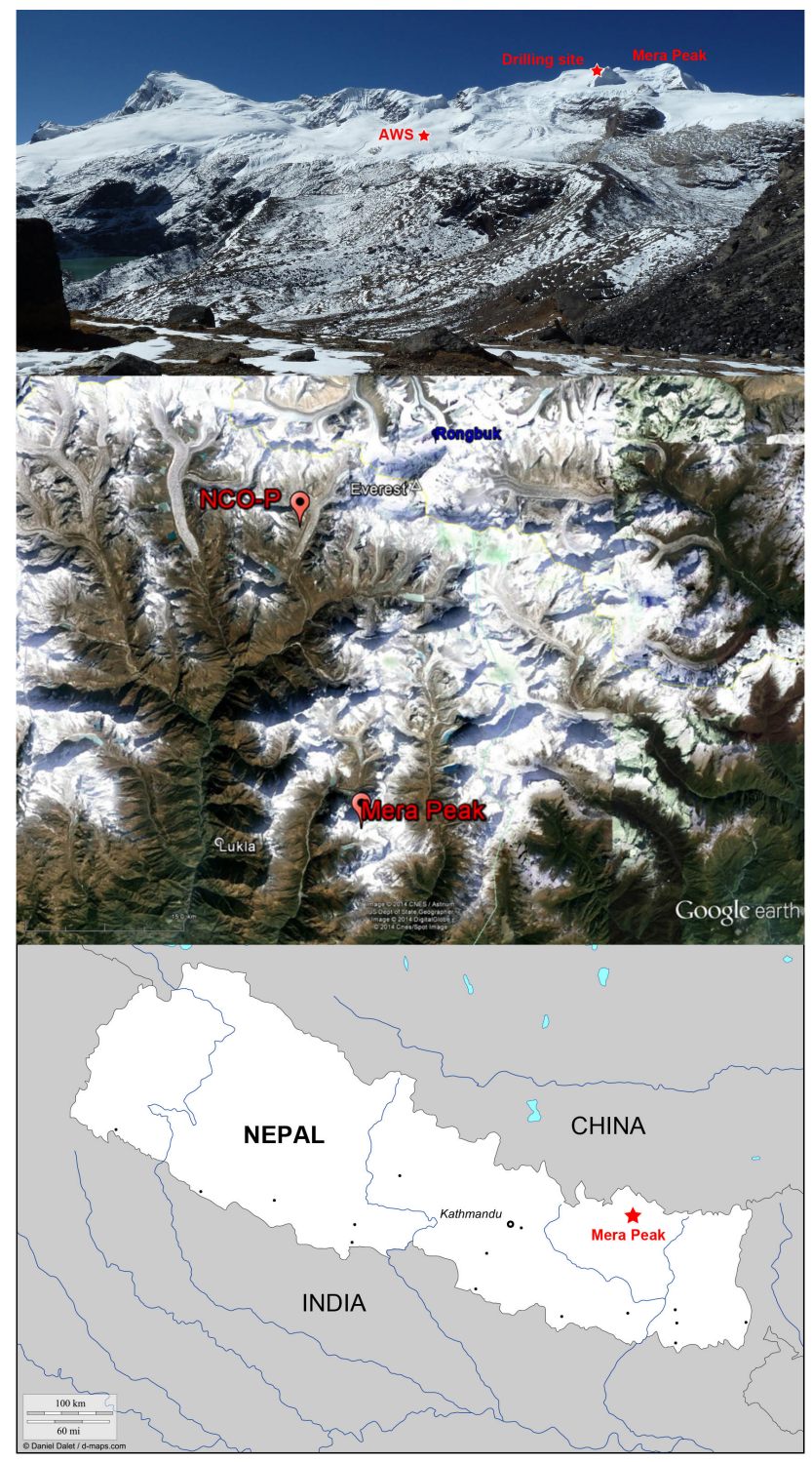

Figure 1. (a) Mera Glacier picture with the position of the drilling site and Naulek weather station, (b) Map of Nepal and border countries showing the location of Mera Peak, (c) Satellite image of the high Dudh Koshi basin where the Mera Glacier and NCO-P sites are located.

pour la Recherche en Environnement) GlacioClim/Himalaya for mass/energy balance (Fig. 1). The selection was also based on the monsoon paths and source areas of natural and anthropogenic compounds, in order to provide reliable records for the monsoon record study.

A $19.8 \mathrm{~m}$ long firn core was extracted using an electromechanical FELICS (Fast Electromechanical Lightweight Ice Coring System) small drill (Ginot et al., 2002) on 11 November 2010 . Borehole temperatures were $-5.7^{\circ} \mathrm{C}$ at a depth of $20 \mathrm{~m},-5.0$ at $15 \mathrm{~m}$ and -3.2 at $10 \mathrm{~m}$ corresponding to a site mean annual temperature below $-5{ }^{\circ} \mathrm{C}$. Core density 
and stratigraphic markers were measured during drilling. The drill core container was a solid aluminum barrel pre-cleaned with ultrapure water before the campaign. Since testing had been carried out previously, sampling in the field, i.e. cutting the core directly into pre-cleaned vials when extracting it from the barrel, did not require any additional decontamination procedure for major ions, stable isotopes, dust and BC. The core was immediately logged and sub-sampled in the field. A total of 276 samples, with an average length of $6.6 \mathrm{~cm}$ (between 4 and $16 \mathrm{~cm}$ ) were stored in 276 sealed precleaned polypropylene vials and kept in an insulated core box for transport. Since it was impossible to be sure the cold chain would be maintained from the glacier to the laboratory, i.e. the samples would probably melt during shipment, a few drops of formaldehyde solution were added to the samples in order to limit the bacteriological development in the vials. Temperature logger in the box recorded that samples were melted during 18 days of shipment before being refrozen in the laboratory.

\subsection{Sample description and analyses}

The core stratigraphy was composed of low density small grains from the surface to $1.5 \mathrm{~m}$ water equivalent ( $\mathrm{m}$ w.e.q.), with a small increase in density to a depth of $2.07 \mathrm{~m}$ w.e.q. Large grain firn was observed below. Ice layers were observed at $1.47-1.57 \mathrm{~m}$ w.e.q., between 1.78 and $2.07 \mathrm{~m}$ w.e.q., and at $4.02 \mathrm{~m}$ w.e.q. (illustrated in Fig. 2).

Analyses of major and organic chemical species were performed using a Dionex ${ }^{\odot}$ ICS3000 dual ion chromatography system at the LGGE laboratory. The chromatography system was used for the analyses of cations $\left(\mathrm{Li}^{+}, \mathrm{Na}^{+}, \mathrm{NH}_{4}^{+}, \mathrm{K}^{+}\right.$, $\left.\mathrm{Mg}^{2+}, \mathrm{Mn}^{2+}, \mathrm{Ca}^{2+} \mathrm{Sr}^{2+}\right)$ and anions $\left(\mathrm{F}^{-}, \mathrm{Cl}^{-}, \mathrm{NO}_{2}^{-}, \mathrm{Br}^{-}\right.$, $\left.\mathrm{NO}_{3}^{-},\left(\mathrm{CH}_{2}\right)_{2} \mathrm{C}_{2} \mathrm{O}_{4}^{2-}, \mathrm{SO}_{4}^{2-}, \mathrm{C}_{2} \mathrm{O}_{4}^{2-}\right)$ down to sub-ppb level and with a high level of accuracy ( 6 standard calibrations, relative standard deviation $<2 \%$ ). The determination of other species was disturbed by the formaldehyde spiking. Insoluble dust measurements were performed using a microparticle counter (Coulter Counter ${ }^{\Theta}$ Multisizer III) for particles with a diameter ranging from 1.0 to $30 \mu \mathrm{m}$, divided in 300 equivalent size channels. The total mass of dust was calculated from the volume size distribution, assuming a density of $2.5 \mathrm{~g} \mathrm{~cm}^{-3}$ (Delmonte et al., 2002). The analytical systems are in the class-100 clean room at the LGGE laboratory, Grenoble, France. Detailed analytical procedures and accuracy are described in Delmonte et al. (2002).

The ${ }^{18} \mathrm{O}$ content of the ice was measured at the HydroSciences LAMA laboratory, Montpellier, France, on an Elementar Isoprime Mass Spectrometer coupled with an Aquaprep module, using the classical $\mathrm{CO}_{2}$ equilibration technique. The results are expressed in $\delta^{18} \mathrm{O}$ on the $\mathrm{V}$ SMOW scale with an overall uncertainty of $\pm 0.06 \%$. Half the samples whose chemical composition was analyzed were used for measurement of $\delta^{18} \mathrm{O}$, which corresponds to a resolution of approximately $12 \mathrm{~cm}$ of snow.

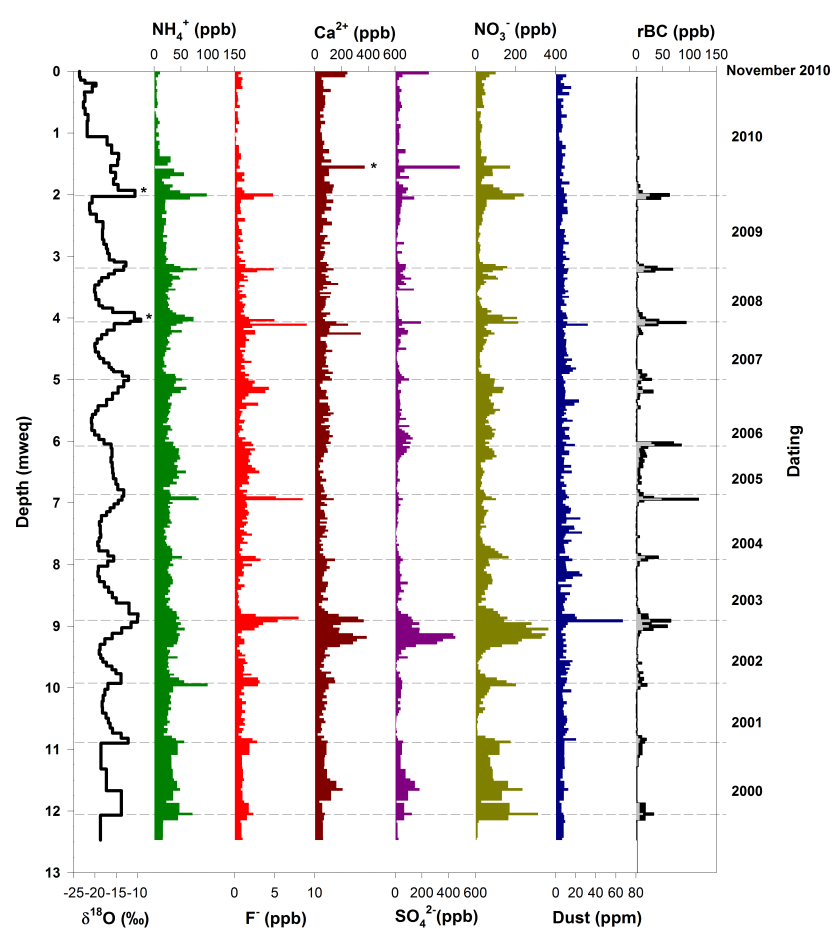

Figure 2. Firn core profiles with depth for water stable isotope $\left(\delta^{18} \mathrm{O}\right)$, ammonium, fluoride, calcium, sulfate, nitrate, dust and refractory black carbon ( $\mathrm{MrBC}$ in gray and $\mathrm{rBC}$ in black) on Mera Glacier. The scale on the right vertical axis corresponds to the annual dry season. The stars correspond to the observed ice layers.

SP2 uses a laser-induced incandescence technique to measure the mass of individual refractory $\mathrm{BC}(\mathrm{rBC})$ independently of $\mathrm{rBC}$ particle morphology and light-scattering coating materials (Petzold et al., 2013; Cross et al., 2010; Moteki and Kondo, 2007, 2010; Schwarz et al., 2006). A single $\mathrm{rBC}$ particle passing through the laser beam intra-cavity absorbs light, reaches a vaporization temperature at which it incandesces, and emits visible thermal radiation. The incandescence signal is proportional to the mass of the individual rBC particle. Fullerene soot was used for calibration of the incandescence signal. The use of SP2 for liquid samples requires nebulization which was performed by an APEX-Q system (EPOND, Switzerland). The efficiency of the APEX/SP2 system was accounted for by applying a correction factor of 0.56 to $\mathrm{rBC}$ mass concentration to all samples (Lim et al., 2014). The nebulization factor was measured every analytical day and the correction was used to obtain the "measured" rBC concentration ( $\mathrm{MrBC}$ ) as done by (Kaspari et al., 2013). In order to calculate the "absolute" rBC concentration, a second correction corresponding to the fraction of $\mathrm{rBC}$ lost during handling of the samples (melting/refreezing cycles principally) had to be applied. In this study, the procedure used comprised two melting/refreezing cycles (Sampling/Melting/Freezing/Melting/Freezing/Melting/Analysis), 
the rBC loss reached $59 \pm 8 \%$ (Lim et al., 2014). The corresponding measured $(\mathrm{MrBC})$ and absolute values $(\mathrm{rBC})$ are used hereafter. For rBC particles, we used the sum of individual $\mathrm{rBC}$ particle mass from $\sim 50$ to $600 \mathrm{~nm}$ mass equivalent diameter to obtain the $\mathrm{rBC}$ mass concentration of each sample. Over the whole record, the highest number of particles appeared between $\sim 50$ and $90 \mathrm{~nm}$ mass equivalent diameters (Lim et al., 2014).

The measurement of equivalent $\mathrm{BC}$ in the atmosphere, resulting from the measured aerosol absorption coefficient, was obtained at NCO-P by MAAP (Multi-Angle Absorption Photometer, ${ }^{\odot}$ Thermo): it measures the transmission and the back scattering of a light beam (Petzold and Schönlinner, 2004) incident on a fiber filter where aerosol particles are deposited by sampling flow. The detection limit ( $3 \sigma$ of blank measurements) was calculated as $11 \mathrm{ng} \mathrm{m}^{-3}$, with an integration time of $30 \mathrm{~min}$ (Marinoni et al., 2010).

\section{Ice core records}

\subsection{Dating}

The firn core was dated annually between 2010 and 1999 based on seasonal cycles of stable isotopes and chemical proxies. In this region, the stable isotope composition of precipitation is mostly controlled by the rainout effect associated with Indian monsoon activity (Araguás-Araguás et al., 1998; Zhang et al., 2001; Vuille et al., 2005). Precipitation data collected over a period of 1 year at the high altitude GNIP Lhajung station $\left(27^{\circ} 53^{\prime} 42^{\prime \prime} \mathrm{N} ; 86^{\circ} 49^{\prime} 30^{\prime \prime} \mathrm{E}\right.$; $4420 \mathrm{~m}$ a.s.l., Nepal) (International Atomic Energy Agency/World Meteorological Organization, 2006), showed depleted values (min $\delta^{2} \mathrm{H}=-130.4 \%$ o) related to the monsoon rain season (June), while enriched values ( $\max \delta^{2} \mathrm{H}=-18.9 \%$ ) corresponding to pre-monsoon season (March-May), resulted in a seasonal amplitude of $111.5 \%$ o for $\delta^{2} \mathrm{H}\left(\approx 13.9 \%\right.$ or for $\delta^{18} \mathrm{O}$ considering the slope of the Global Meteoric Water Line). The clear variation in $\delta^{18} \mathrm{O}$ recorded along the core, about $10 \%$ o in amplitude (Fig. 2) can be safely attributed to seasonal cycles, with the depleted phase corresponding to the monsoon season and the enriched peaks to inter-monsoon periods. Since precipitation is reduced during inter-monsoon seasons at high altitude, part of the enriched events may be missing from the record due to wind erosion of the snow (Wagnon et al., 2013) resulting in a reduced seasonal amplitude compared to drain water values.

The variation in chemical tracers in the ice core was used to complete the stable isotope records for dating purposes. In order to observe the highest seasonal variability in the chemical composition, we focused on species subjected to a combination of deposition processes like scavenging and post-deposition enrichment (Ginot et al., 2001). The difference between the wet monsoon and the dry inter-monsoon and their related aerosol sources and deposition processes is amplified with this approach. Ammonium ions $\left(\mathrm{NH}_{4}^{+}\right)$are a good indicator. The potential sources of ammonia in this region are biomass burning, farming and soil emissions resulting from the use of nitrogen fertilizers (Sun et al., 1998).

As observed in the atmospheric record at NCO-P (Decesari et al., 2010), $\mathrm{NH}_{4}^{+}$undergoes strong seasonal variability in the same way as the main aerosol chemical constituents. The atmospheric concentration of ammonium ranged from a minimum of $<0.023-0.14 \mu \mathrm{g} \mathrm{m}^{-3}$ in the afternoon during the monsoon to a maximum of $0.40 \mu \mathrm{g} \mathrm{m}^{-3}$ in the afternoon in the pre-monsoon period with minima during the monsoon and maxima during the pre-monsoon period. In the monsoon season, $\mathrm{NH}_{4}^{+}$is efficiently washed out by precipitation and does not reach the high Himalayas leading to annual minima (Decesari et al., 2010; Carrico et al., 2003). During the post-monsoon period and winter, which correspond to drier conditions, a rise in $\mathrm{NH}_{4}^{+}$concentration is observed in the atmosphere and a clear strong peak is usually recorded during the pre-monsoon season. Dry and wet deposition processes of both particulate $\mathrm{NH}_{4}^{+}$and gaseous $\mathrm{NH}_{3}$ result in high concentration peaks on the surface snow, which may subsequently be amplified by post-depositional processes such as snow sublimation (Ginot et al., 2001) or reaction with $\mathrm{HNO}_{3}$ absorbed on the snow layers (Marinoni et al., 2001; Shrestha et al., 2002). In winter, westerly circulation associated with distant or reduced sources may generate low $\mathrm{NH}_{4}^{+}$concentration in the snow layers; but these layers are usually scarce (very dry conditions in winter) and often not preserved in the snow column (snow remobilized into the atmosphere due to strong winds at high elevations in winter, Wagnon et al., 2013). The ammonium core profile was therefore used for dating, with high concentration peaks corresponding to the annual dry season (Fig. 2).

Stable isotopes were consequently used to identify each annual cycle between November 2010 and the year 2000 from the annual enriched peak (dashed lines in Fig. 2). The section between two consecutive enriched peaks was used to calculate an annual mean. Because accumulation is not linear with time, we used the isotopic cycle to split the year into two seasons. For each year, the section with more depleted values than the annual mean were identified as monsoon precipitation and their borders were dated using the monsoon onset and withdrawal dates provided by the Department of Hydrology and meteorology (Government of Nepal, Katmandu: http://www.dhm.gov.np/uploads/climatic/ 535305507monsoon\%20onset\%20n\%20withdrawal.pdf).

The additional sections were identified as inter-monsoon season. Each core sample was dated using a linear depth versus time trend between the two monsoon onset and withdrawal dates. The use of the annual mean isotopic value as the seasonal border may induce some uncertainties in the dating at the monthly resolution but also in the seasonal accumulation distribution and the seasonal concentration. However, annual values are not sensitive to this dating method. 
Isotopic and chemical dating methods resulted in a seasonally resolved dated profile from November 2010 to the year 2000 (Fig. 2). The lowest $\mathrm{NH}_{4}^{+}$concentration layer observed between the surface and $1.19 \mathrm{~m}$ water equivalent (w.e.) depth, also corresponded to the most depleted $\delta^{18} \mathrm{O}$ over the whole profile; it was atypical of the profile and was related to the temporary preservation of early snow from September to November 2010. This layer was composed of cold small loose snow grains in contrast to the deeper part of the core, which was composed of more compact, larger and transformed snow crystals and ice layers. No other early winter snow layer was preserved elsewhere in the profile probably because of strong wind erosion and remobilization of loose snow during winter, as systematically observed on-site by (Wagnon et al., 2013) since 2007.

The profile was divided into three seasonal patterns. As mentioned above, only a single winter event was identified between the surface and $1.19 \mathrm{~m}$ w.e. depth. The snow fraction related to monsoon and inter-monsoon conditions was attributed according to the $\delta^{18} \mathrm{O}$ composition. Along the profile, $46 \%$ of the core was attributed to "monsoon", $47 \%$ to "inter-monsoon" and $7 \%$ to "winter" layers.

Accumulation measured close to the drilling site for the time frame 2008-2013 (Wagnon et al., 2013) ranged between 0.38 and $1.25 \mathrm{~m}$ w.e.q. with a mean of $0.83 \mathrm{~m}$ w.e.q. The core, with $12.47 \mathrm{~m}$ w.e.q. and spanning 2000-2010 corresponded to a mean net accumulation of $1.13 \mathrm{~m}$ w.e.q. Two years accumulation 2008-2009 and 2009-2010 are compared and reveals higher accumulation from the ice core study with respectively 2.14 and $1.26 \mathrm{~m}$ w.e.q. from the core and 0.72 and $0.83 \mathrm{~m}$ w.e.q. from Wagnon et al. (2013) study. In comparison, at NCO-P site at $5035 \mathrm{~m}$ a.s.l., annual mean precipitation for 2007-2012 was 389 $\pm 44 \mathrm{~mm}$ but solid precipitation was likely underestimated (Wagnon et al., 2013).

\subsection{Observed concentration profiles, deposition processes and seasonal variations}

The ice core record was characterized by strong seasonality that can be sub-divided into three distinct patterns corresponding to winter, monsoon and inter-monsoon. Table 1 summarizes the concentrations of major ions, dust and $\mathrm{rBC}$ for the whole core and for the three distinct periods. The "winter" column is only based on data from the available layer covering September to November 2010.

Whereas the concentrations of major ions $\left(\mathrm{NH}_{4}^{+}, \mathrm{NO}_{3}^{-}\right.$, $\mathrm{SO}_{4}^{2+}, \mathrm{Ca}^{2+}, \mathrm{F}^{-}$) were in the same order of magnitude as those observed by Ming et al. (2007) at the East Rongbuk Glacier on the northern side of the Himalayas, the aerosol sources or deposition processes at our study site, characterized with species ratios, differed from elsewhere. In our study, $\mathrm{Ca}^{2+}$ was the major ion in agreement with the high dust concentrations observed in the atmosphere at NCO-P (Decesari et al., 2010). The mean concentration ratio $\left[\mathrm{Ca}^{2+}\right] /\left[\mathrm{SO}_{4}^{2-}\right]$ was 4.33 , as opposed to only 0.23 recorded in the aerosol/snow study at the East Rongbuk Glacier site on the Northern Himalayan slope (Ming et al., 2007). According to the ionic balance ( $\Sigma$ cations $-\Sigma$ anions), which were mostly negative, and the high $\left[\mathrm{Ca}^{2+}\right] /\left[\mathrm{SO}_{4}^{2-}\right]$ ratio, calcium appears to be mostly in the form of calcium carbonate $\left(\mathrm{CaCO}_{3}\right)$ rather than gypsum $\left(\mathrm{CaSO}_{4}\right)$.

The $\mathrm{rBC}$ averaged level in the ice core was $7.43 \pm 15.07 \mu \mathrm{g} \mathrm{L}^{-1}$, with a higher mean concentration during the inter-monsoon season $\left(13.50 \pm 20.00 \mu \mathrm{g} \mathrm{L}^{-1}\right)$ and a lower mean concentration in the monsoon season $\left(2.15 \pm 3.45 \mu \mathrm{g} \mathrm{L}^{-1}\right)$. The maximum $\mathrm{rBC}$ concentration measured in the 10 year profile was $116.83 \mu \mathrm{g} \mathrm{L}^{-1}$ (Table 1). These values can be compared with previous studies on ice cores in Tibetan Plateau, such as Ming et al. (2008) and Kaspari et al. (2011), although the different techniques and corrections used means they are not directly comparable (Petzold et al., 2013). The concentrations measured at Repula Col by Ming et al. (2008) using thermal-optical methods for present conditions were higher $\left(20.3 \pm 9.2 \mu \mathrm{g} \mathrm{L}^{-1}\right)$ but lower than those analyzed at East Rongbuk glacier using the SP2 method (Kaspari et al., 2011): only $0.7 \pm 1.0 \mu \mathrm{g} \mathrm{L}-1$ of ${ }_{\mathrm{M}} \mathrm{rBC}$. At the Mera Glacier, the concentration reported by (Kaspari et al., 2013) for the sample taken in a snow pit on Mera Col (6400ma.s.1.) were compared with those measured in this study. Maximum and mean ${ }_{\mathrm{MrBC}}$ values are in the same order of magnitude with respectively $8.4 \mu \mathrm{g} \mathrm{L}^{-1}$ and $1.0 \mu \mathrm{g} \mathrm{L}^{-1}$ in the snow pit and $47.90 \mu \mathrm{g} \mathrm{L}^{-1}$ and $3.04 \mu \mathrm{g} \mathrm{L}^{-1}$ in this core study. The higher maximum value of the ice core is the result of a longer time record with higher resolution and greater temporal variability.

The mean concentration of insoluble dust was high (10.1 $\left.\mathrm{mg} \mathrm{L}^{-1}\right)$, with only few spikes up to $66.9 \mathrm{mg} \mathrm{L}^{-1}$ before the 2003 monsoon layer. This is much higher than the mean concentration $\left(0.465 \mathrm{mg} \mathrm{L}^{-1}\right)$ measured in the ice core taken from the opposite slope of Mount Everest, in the central Himalayas (Xu et al., 2010). The relative lack of seasonality in both the overall quantity and the size distribution in the dust record is surprising but may reflect the impact of a high background level of dust inputs, whether from a local or a regional source. Figure 3 shows the mean size distribution of dust for the three periods of interest. The presence of large particles $(>10 \mu \mathrm{m})$ was confirmed for all three periods as was the similar modal size distribution of dust between winter, monsoon and inter-monsoon seasons, with a mean mass equivalent diameter of 5.7, 6.0 and $6.4 \mu \mathrm{m}$ respectively. Mean dust concentrations showed some seasonal differences with a lower concentration in winter $\left(7.2 \mathrm{mg} \mathrm{L}^{-1}\right)$ and higher concentrations during the monsoon $\left(10.1 \mathrm{mg} \mathrm{L}^{-1}\right)$ and inter-monsoon $\left(11.1 \mathrm{mg} \mathrm{L}^{-1}\right)$ periods. These values are in agreement with observations made by (Gobbi et al., 2010) using a sun photometer but contradict observations made at NCO-P by Marinoni et al. (2010). The layer with the highest concentration of dust $\left(66.9 \mathrm{mg} \mathrm{L}^{-1}\right)$ (Fig. 2) was recorded at $8.9 \mathrm{~m}$ w.e. depth with a larger mean mass equivalent diameter of $10 \mu \mathrm{m}$. This event could be associated with the major dust 
Table 1. Summary data: EOF analysis parameters and aerosol concentrations and fluxes obtained from the Mera Glacier ice core.

\begin{tabular}{|c|c|c|c|c|c|c|}
\hline & & All/annual & Inter-monsoon & Monsoon & Winter & \\
\hline & samples & 276 & $130(47 \%)$ & $127(46 \%)$ & $19(7 \%)$ & \\
\hline & ice core & $19.8 \mathrm{~m}$ & $8.37 \mathrm{~m}$ & $7.80 \mathrm{~m}$ & $2.03 \mathrm{~m}$ & \\
\hline & & 12.47 m,w.e.q. & 5.28 m w.e.q. & 4.94 m w.e.q. & 0.99 m w.e.q. & \\
\hline $\mathrm{PC} 1$ & Variance & $37 \%$ & $41 \%$ & $38 \%$ & $50 \%$ & \\
\hline $\mathrm{PC} 2$ & variance & $20 \%(58 \%)$ & $19 \%(60 \%)$ & $20 \%(59 \%)$ & $18 \%(68 \%)$ & \\
\hline PC3 & variance & $13 \%(71 \%)$ & $15 \%(75 \%)$ & $10 \%(69 \%)$ & $12 \%(78 \%)$ & \\
\hline$\delta^{18} \mathrm{O}$ & mean composition & $-17.21 \pm 2.95$ & $-14.62 \pm 2.11$ & $-18.63 \pm 1.38$ & $-21.98 \pm 1.15$ & $(\% \circ)$ \\
\hline $\mathrm{NH}_{4}^{+}$ & mean concentration & $1.69 \pm 0.84$ & $2.03 \pm 0.94$ & $1.52 \pm 0.44$ & $0.30 \pm 0.13$ & $\left(\mu \mathrm{Eq} . \mathrm{L}^{-1}\right)$ \\
\hline $\mathrm{F}^{-}$ & mean concentration & $0.070 \pm 0.060$ & $0.091 \pm 0.078$ & $0.055 \pm 0.024$ & $0.027 \pm 0.014$ & $\left(\mu \mathrm{Eq} . \mathrm{L}^{-1}\right)$ \\
\hline $\mathrm{Ca}^{2+}$ & mean concentration & $4.52 \pm 2.77$ & $4.63 \pm 2.89$ & $4.46 \pm 2.68$ & $4.12 \pm 2.85$ & $\left(\mu \mathrm{Eq} \cdot \mathrm{L}^{-1}\right)$ \\
\hline $\mathrm{SO}_{4}^{2-}$ & mean concentration & $1.05 \pm 1.28$ & $1.10 \pm 1.34$ & $0.95 \pm 1.26$ & $0.90 \pm 1.08$ & $\left(\mu \mathrm{Eq} . \mathrm{L}^{-1}\right)$ \\
\hline $\mathrm{NO}_{3}^{-}$ & mean concentration & $1.07 \pm 0.97$ & $1.31 \pm 1.13$ & $0.85 \pm 0.74$ & $0.64 \pm 0.32$ & $\left(\mu \mathrm{Eq} . \mathrm{L}^{-1}\right)$ \\
\hline \multirow[t]{3}{*}{$\mathrm{MrBC}$} & max. concentration & 47.90 & 47.90 & 8.15 & 1.20 & $\left(\mu \mathrm{g} \mathrm{L}^{-1}\right)$ \\
\hline & mean concentration & $3.04 \pm 6.11$ & $5.53 \pm 8.20$ & $0.88 \pm 1.41$ & $0.34 \pm 0.23$ & $\left(\mu \mathrm{g} \mathrm{L}^{-1}\right)$ \\
\hline & deposition flux & $3.2 \pm 1.2$ & $(87 \% \pm 10 \%)$ & $(13 \% \pm 10 \%)$ & & $\left(\mathrm{mg} \mathrm{m}^{-2} \mathrm{y}^{-1}\right)$ \\
\hline \multirow[t]{3}{*}{$\mathrm{rBC}$} & max. concentration & 116.83 & 116.83 & 19.88 & 2.92 & $\left(\mu g \mathrm{~L}^{-1}\right)$ \\
\hline & mean concentration & $7.43 \pm 15.07$ & $13.50 \pm 20.00$ & $2.15 \pm 3.45$ & $0.84 \pm 0.56$ & $\left(\mu \mathrm{g} \mathrm{L}^{-1}\right)$ \\
\hline & deposition flux & $7.9 \pm 2.8$ & $(87 \% \pm 10 \%)$ & $(13 \% \pm 10 \%)$ & & $\left(\mathrm{mg} \mathrm{m} \mathrm{m}^{-2} \mathrm{y}^{-1}\right)$ \\
\hline \multirow[t]{3}{*}{ Dust } & max. concentration & 66.9 & 66.9 & 26.5 & 15.4 & $\left(\mathrm{mg} \mathrm{L}^{-1}\right)$ \\
\hline & mean concentration & 10.1 & $10.6 \pm 6.6$ & $10.1 \pm 4.0$ & $7.6 \pm 3.2$ & $\left(\mathrm{mg} \mathrm{L}^{-1}\right)$ \\
\hline & deposition flux & $10.4 \pm 2.8$ & $(54 \% \pm 20 \%)$ & $(46 \% \pm 20 \%)$ & & $\left(\mathrm{g} \mathrm{m}^{-2} \mathrm{y}^{-1}\right)$ \\
\hline
\end{tabular}

outbreak over south Asia in June 2003 described by (Gautam et al., 2013). The process by which dust is deposited onto snow at Mera Glacier is uncertain, but concentrations are clearly higher than would be expected according to atmospheric measurements made at NCO-P.

As dust deposition fluxes were high in all three seasons, we used the available data to track changes in the sources of dust. Soluble species analyzed by ion chromatography, including calcium, magnesium, manganese, lithium and strontium, were used to calculate the ratios of soluble ionic species to dust. The negative ionic balance was attributed to the carbonate load. These ratios and carbonate were used to identify changes in the sources of dust. The ionic balance was negative throughout the record $\left(-6.7 \mu \mathrm{Eq} \mathrm{L}^{-1}\right.$ mean value); the lowest values were lower for winter snow $\left(-4.5 \mu \mathrm{Eq} \mathrm{L}^{-1}\right)$ and some spikes reached between -20 and $-40 \mu \mathrm{EqL}^{-1}$. The calcium : dust ratio remained relatively stable throughout the record. The two dustiest layers located in inter-monsoon periods, at depths of 4.1 and $8.9 \mathrm{~m}$ w.e., are atypical (Fig. 2). These layers had the highest carbonate concentration and high ratios of manganese and magnesium, which may have been characteristics of a different dust source we were not able to identify. A third source, with high a lithium ratio associated with sea salt, with or without carbonate, appeared in the most recent part of the record (winter and the monsoon season in 2010), and could represent inputs of aerosols from salt flats or salt lakes located on the Tibetan plateau.
Using $\mathrm{SO}_{4}^{2-}$ as a reference, the snow was clearly enriched in $\mathrm{NO}_{3}^{-}$and $\mathrm{NH}_{4}^{+}$compared with the atmosphere. While $\mathrm{NO}_{3}^{-} / \mathrm{SO}_{4}^{2-}$ and $\mathrm{NH}_{4}+/ \mathrm{SO}_{4}^{2-}$ rarely exceed 1 (average $=0.42$ and 0.50 respectively) in the atmosphere (Decesari et al., 2010), they were much higher in our ice samples (average $=1.32$ and 2.89, respectively). This is certainly due to negative artifacts on the filters leading to loss of $\mathrm{NO}_{3}^{-}$ (and to a lesser extent of $\mathrm{NH}_{4}^{+}$) but also to efficient scavenging (wet and dry) of highly soluble $\mathrm{NH}_{3}$ and $\mathrm{HNO}_{3}$ gases to snow surfaces.

Empirical Orthogonal Function (EOF) can be used to analyze the behaviour of the different species. Variance analysis of all the samples was first performed. Not surprisingly, most of the variability $\left(\mathrm{PC} 1=37 \%\right.$, all species: $\mathrm{rBC}, \delta^{18} \mathrm{O}$, dust and major ions) was mainly controlled by the deposition processes that were used for dating purposes. All the concentrations of ions, dust and rBC correlated with low (high) concentrations during the wet (dry) season. Low concentrations were due to dilution during the wet season, high concentrations corresponded to post-deposition processes (dry deposition and sublimation) during the dry season. $\delta^{18} \mathrm{O}$ and soluble ionic species were in phase with depleted (enriched) isotopic values with low (high) concentrations. The seasonal variation in dust does not appear clearly in Fig. 2 and the association of $\mathrm{PC} 1$ is driven by sporadic peaks during the intermonsoon period. PC2 and PC 3 explained limited variance (20 and $13 \%$ respectively) but, as observed in the projection (Supplement), can be used to differentiate sources containing 


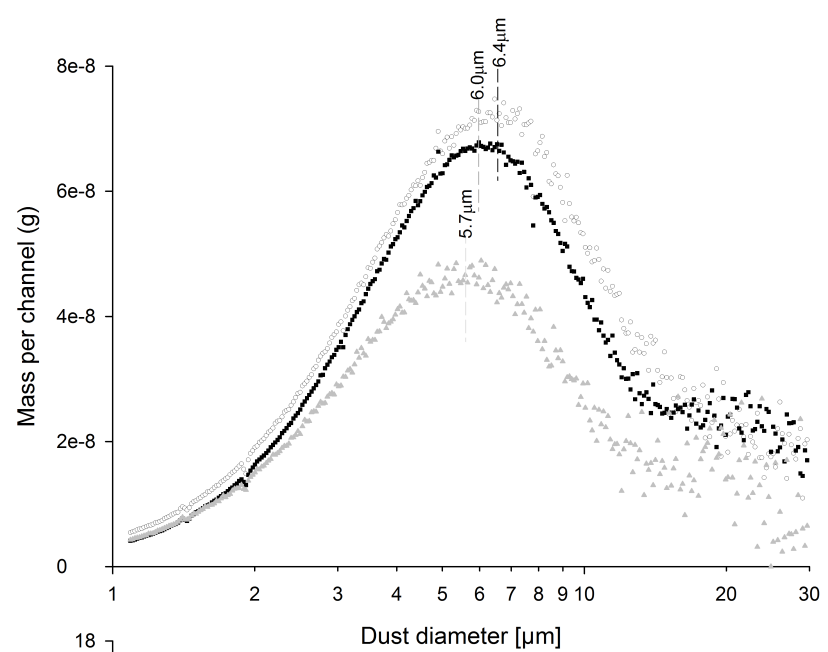

City (MACC/CityZEN EU projects) inventories (Granier et al., 2011; Lamarque et al., 2010; Diehl et al., 2012; Van der Werf et al., 2006), we calculated the temporal variability of anthropogenic and natural emissions for the area of northern India/Pakistan that most influence the high Himalayan regions (area selected: India+). During the 1999-2010 period, anthropogenic emissions of $\mathrm{SO}_{2}, \mathrm{NO}_{\mathrm{x}}$ and $\mathrm{BC}$ were estimated to have increased by 56,45 and $20 \%$, respectively. No trends emerged for anthropogenic $\mathrm{NH}_{3}$ emissions, or for biomass burning emissions of $\mathrm{rBC}$, sulfate, nitrate and ammonium. Also in Fig. 2, no trend can be detected in the ice core record for any of the species concerned over the last 10 years. Emission intensity peaks occurred during the winter period, but not associated with the highest concentrations in the ice core record as the winter snow layers were not preserved. Thermal breezes or weak convective processes limited efficient transport from the Indo-Gangetic plains to higher altitudes during that period as observed at the NCO-P site (Marinoni et al., 2010; Bonasoni et al., 2010). Compared in terms of fluxes over the 10-year period, the variability of the ice core signal rather reflects the variability of the monsoon signal than that of emission intensity in the India + area. This is an important result for studies connecting BC emissions to their impact on the cryosphere.

\subsection{Comparison with the aerosol record at NCO-P}

Atmospheric composition has been continuously measured at NCO-P since March 2006 (Fig. 4). We were consequently able to compare the atmospheric observations recorded at NCO-P with the signal recorded in the Mera ice core during the overlap period, i.e. from 2006 to 2010. NCO-P and Mera Glacier are located $27 \mathrm{~km}$ apart and their difference in elevation is $1300 \mathrm{~m}$. However, because the ice core signal intensity is a complex mixture of wet scavenging, dry deposition, and post-depositional processes, it is therefore difficult to directly link intensity with an atmospheric signal. In addition, the techniques used to reconstruct the ice core signal generally differ from those used in the atmosphere and cannot be easily compared. At NCO-P, PM $_{10}$ filters are regularly sampled and analyzed, and elemental and organic carbon as well as major ion concentrations are measured. Black carbon is measured by single-particle incandescence, correlated with black carbon mass in the snow, and derived from the aerosol absorption coefficient in the atmosphere. Very few comparisons of these two techniques are available. Dust in the ice core sample was measured with a Coulter Counter ${ }^{\odot}$ and approximated by the $\mathrm{PM}_{10}-\mathrm{PM}_{1}$ signal of the optical particle counter (OPC) in the atmosphere at NCO-P. Similarly, without additional information on shape, density, and the refractive index, the two records cannot be compared quantitatively. However, similarities and differences can be pointed out.

Comparisons between the ice core signal at Mera Glacier and the atmospheric observations at NCO-P are shown in Fig. 4 for black carbon and dust. To reconstruct the two 


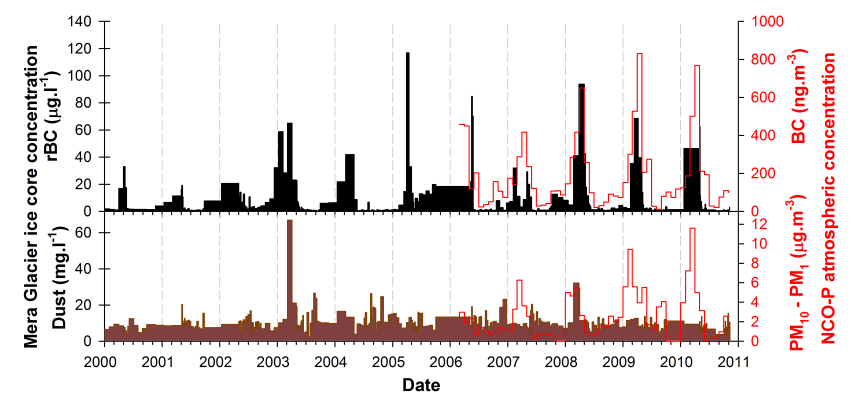

Figure 4. Atmospheric $\mathrm{BC}$ and dust (red lines, scales on the right vertical axis) measured monthly at the NCO-P site, and changes in surface snow concentrations of rBC (black bar, scales on the left vertical axis) and dust (drown bar) reconstructed from dated firn core data.

signals along the same temporal axis, we used the continuous observations made at NCO-P, and for the firn core, we converted the depth scale to a time scale using the following procedure. The seasonally resolved record made it possible to reconstruct changes in concentrations of $\mathrm{rBC}$ and dust in surface snow. The monsoon onset and withdrawal date tie points identified along the core were used for dating and linear dating with depth was used between the points as described above (Fig. 4).

Both atmospheric and ice core records showed strong seasonality with the lowest values during the monsoon season and the highest values during the inter-monsoon (or premonsoon) season. The conjunction of emission, transport and deposition (wet or dry) processed favoured the presence of short-lived species (particularly BC) in the snow during the period from February to June. The variability of the dust signal was much less pronounced in the ice core signal than in the atmospheric signal, as can be seen in Figs. 2 and 4. The ratio mass of dust to $\mathrm{rBC}$ in the ice core signal was much higher than that of $\left(\mathrm{PM}_{10}-\mathrm{PM}_{1}\right)$ to the equivalent $\mathrm{BC}$ in the atmosphere. This is an additional confirmation of the presence of a local dust source, formed by coarse particles not sampled in the $\mathrm{PM}_{10}$ inlet at NCO-P.

\subsection{Dust and rBC deposition fluxes}

Annual deposition fluxes can be compared at the two sites with a few assumptions for the overlap period 2006-2010. Here we limited the calculation to $\mathrm{BC}$ from atmospheric measurements using the deposition velocities derived by Yasunari et al. (2010, 2013). For the pre-monsoon season 2006, (Yasunari et al., 2010) obtained a total BC deposition of $0.266 \mathrm{mg} \mathrm{m}^{-2}$ at NCO-P. Changes in concentrations in the surface snow over time were simulated using the firn core data and the dating procedure described previously and illustrated in Fig. 4. This reconstruction was used to simulate the impact of surface snow impurities on the glacier energy balance and on melting (Sect. 4.3).
Deposition fluxes for $\mathrm{rBC}$ and insoluble dust were calculated from the ice core data. Annual mean deposition fluxes (from 1 October to 30 September) over the last 10 years were $7.9 \pm 2.8 \mathrm{mg} \mathrm{m}^{-2} \mathrm{y}^{-1}$ for $\mathrm{rBC}$ and $10.4 \pm 2.8 \mathrm{~g} \mathrm{~m}^{-2} \mathrm{y}^{-1}$ for dust. The rBC value is in the upper range of fluxes modelled by Yasunari et al. (2013) for this region of the Himalayas, and one order of magnitude higher than that calculated from measurements made at the NCO-P site in the pre-monsoon season (Yasunari et al., 2010). Furthermore, these fluxes were calculated between monsoon and intermonsoon regimes. When we split the seasonal fluxes between "monsoon" and "inter-monsoon", rBC and dust displayed different behaviours. The mean dust concentration remained stable over all the seasons with $10.6 \pm 6.6 \mathrm{mg} \mathrm{L}^{-1}$ during the inter-monsoon period and $10.1 \pm 4.0 \mathrm{mg} \mathrm{L}^{-1}$ during the monsoon. The deposition flux in the inter-monsoon period accounted for $54 \%$ of the annual flux. In contrast, the rBC deposition flux was concentrated in the inter-monsoon period and accounted for $87 \%$ of the annual deposition, and with a larger difference in mean concentration between the seasons $\left(13.5 \mu \mathrm{g} \mathrm{L}^{-1}\right.$ during the inter-monsoon period, and $2.15 \mu \mathrm{g} \mathrm{L}^{-1}$ during the monsoon).

\section{Impact of dust and $\mathrm{rBC}$ on surface albedo and glacier melting}

\subsection{Changes in albedo due to $\mathrm{BC}$ and dust deposition}

For this study, we used the reconstructed aerosol concentration based on the ice core to investigate the impact of dust and $\mathrm{rBC}$ contents of the snow surface on its energy balance through changes in surface albedo. Our approach was to simulate the changes in albedo produced by different concentrations of impurities, dust and $\mathrm{rBC}$, measured in the ice core. To this end, we used the radiative transfer model DISORT (Discrete Ordinate Radiative Transfer Model) (Stamnes et al., 1988) with several simplistic assumptions, since our aim was just to estimate the order of magnitude of the effects of impurities on the snow radiation balance.

As shown in Fig. 2, rBC concentration peaks built up during the drier period between each annual monsoon event. According to observations made at the NCO-P site (Marinoni et al., 2010), the highest atmospheric concentration of BC occurred during the pre-monsoon season (February to May) transported both by valley breezes from the Indo-Gangetic Plain (India, Nepal) and by longer range air masses from Middle Eastern and European sources. The difference in the deposition of $\mathrm{BC}$ and other tracers of anthropogenic activities, like ammonium and fluoride, confirmed the regional source of the "brown cloud".

Snow grains were considered to be spherical and we used Mie theory to compute their single scattering properties. The refractive index of ice was taken from Warren and Brandt (2008). The refractive index of BC and its density was taken 
from Flanner et al. (2012) whereas the refractive indices and density of dust with different hematite contents were taken from Balkanski et al. (2007). The DISORT model was used to simulate the spectral albedo of an external or internal mixture of impurities and snow as detailed in Flanner et al. (2012). In the absence of any measurement, the snow grain size was chosen as constant in preference to the profile (optical radius (r_opt) of $0.16 \mathrm{~mm}$ or $0.65 \mathrm{~mm}$ ) and the impurities were equally distributed within the snowpack (internal or external).

Dust and BC contents were computed from the seasonally dated core record. Dust was considered as being external to the snow grains given its size (mass equivalent diameter ranging from $6 \mu \mathrm{m}$ when deposited with precipitation up to $10 \mu \mathrm{m}$ when transported dry). BC was assumed to be external during the dry season (dry deposition) and internal during the monsoon (wet deposition). The mean diameter used for BC was $90 \mathrm{~nm}$ for all seasons as shown by SP2 measurements.

The simulated spectral albedo using DISORT for 1 March 2003 and 1 April 2005 and for diffuse irradiance is illustrated in Fig. 5. These two dates were chosen as they represent extreme values of dust and $\mathrm{rBC}$ concentrations in the record at the end of the simulated post-monsoon season. For March 2003, $\mathrm{M}_{\mathrm{rBC}}$ content was $23.97 \mathrm{ppb}$ and dust content was $57.1 \mathrm{ppm}$, whereas for April 2005, $\mathrm{MrBC}$ content was $42.38 \mathrm{ppb}$ and dust content was $10.69 \mathrm{ppm}$. The solid blue line corresponds to the albedo of pure fine snow (r_opt $=0.16 \mathrm{~mm}$ ) while the black solid line corresponds to the albedo of fine snow containing both rBC and dust. Different hematite content were simulated. The two light blue lines in the right panel correspond to the spectral albedo of pure and contaminated snow for coarser grains ( $\mathrm{r} \_\mathrm{opt}=0.65 \mathrm{~mm}$ ). For these simulations, we chose a hematite content of $1.5 \%$ for the dust refraction index which corresponds to the average content determined by Balkanski et al. (2007). In the 350-500 $\mathrm{nm}$ range for fine grains, impurities caused a decrease of 0.1 point in the value of the albedo for March 2003 whereas dust alone caused a decrease of 0.05 for April 2005 ( 0.1 for 2003) and $\mathrm{rBC}$ alone caused a decrease of 0.05 for the 2 years. These figures explain why the impurities have a non-linear effect on the value of the albedo. Indeed $\mathrm{rBC}$ and dust combined have less effect than the sum of the effects of $\mathrm{rBC}$ alone and dust alone. This can be easily explained by the fact that a mixture of impurities and snow has a much higher absorption coefficient (imaginary part of the refractive index) than pure snow. Thus, adding one type of impurity to the snow reduces the impact of the other impurity compared to the impact of the same amount of the impurity on pure snow. In other words, the higher the absorption coefficient, the lower the impact of supplementary impurities will be. The effect of snow grain size is also noticeable in this figure 5 when comparing the simulations. The same amount of impurities has more effect on coarse grain snow than on fine grain snow. Indeed, the decrease in albedo due to impurities in the visible range is at least two times higher for coarse grains than for fine grains since photons generally travel a greater distance in the snow pack for coarser grains (Warren and Wiscombe, 1980). Different hematite contents were tested, minimum $(0.9 \%)$ and maximum $(2.7 \%)$ according to Balkanski et al. (2007), and are illustrated in Fig. 5, showing the impact on the albedo of the refractive index of dust chosen in the simulation. In the following, we only use the average value of $1.5 \%$ for hematite content.

\subsection{Additional absorbed energy}

To evaluate the amount of additional solar energy absorbed by the snowpack due to the presence of impurities, we estimated mean solar irradiance and its characteristics. Solar irradiance was computed using the radiative transfer model SBDART (Santa Barbara DISTORT Atmospheric Radiative Transfer Model) (Ricchiazzi et al., 1998). SBDART is based on the same computation rules as DISORT. It considers an atmosphere made up of different plane-parallel layers. The characteristics of the atmospheric profiles (aerosols, water vapour, ozone, etc.) were set according to the location of the site. The solar zenith angle was selected according to location and time of day. The sky was assumed to be clear for all the days in the clear sky simulation and cloudy for all the days in the cloudy simulation. Simulations were run for the 1 st and the 15th of each month for the 11 years of the study. For each simulation day, the absorbed energy was calculated at 05:00 a.m., 08:00 a.m., 10:00 a.m., 12:00 p.m., 02:00 p.m. and 04:00 p.m. local time and the daily absorbed energy was computed from these simulations. The absorbed energy was then interpolated from these simulations on a daily basis for the whole period.

Figure 6 shows the mean daily surface forcing due to impurities for the year 2003. These daily values correspond to the difference between the solar energy absorbed by a pure snowpack and the energy absorbed by a contaminated snowpack. The simulation shows that the radiative forcing of impurity reached maximum in the pre-monsoon season, up to $27 \mathrm{~W} \mathrm{~m}^{-2}$ for clear sky and coarse grain snow, as also observed in a MODIS investigation (Gautam et al., 2013). For $2003,75 \%$ of the radiative forcing was attributed to the presence of dust in the snowpack. Figure 6 also shows that radiative forcing was almost twice higher for coarse snow (r_opt $=0.65 \mathrm{~mm}$ ) than for fine snow $\left(r_{-}\right.$opt $\left.=0.16 \mathrm{~mm}\right)$. These results are comparable with those of Sterle et al. (2013) in the Sierra Nevada. The cloudy sky simulation halved the radiative forcing of the clear sky simulation (maximum radiative forcing of $16 \mathrm{~W} \mathrm{~m}^{-2}$ for coarse snow grains).

The whole period covered by the ice core, 2000-2010 was then simulated (Fig. 7) and clearly revealed high dust content to be mainly responsible for most of the additional absorbed energy. Kaspari et al. (2013) study on Mera Glacier also suggest that $\mathrm{BC}$ contributes little forcing when large dust concentration is present. Except for some high peaks in rBC 

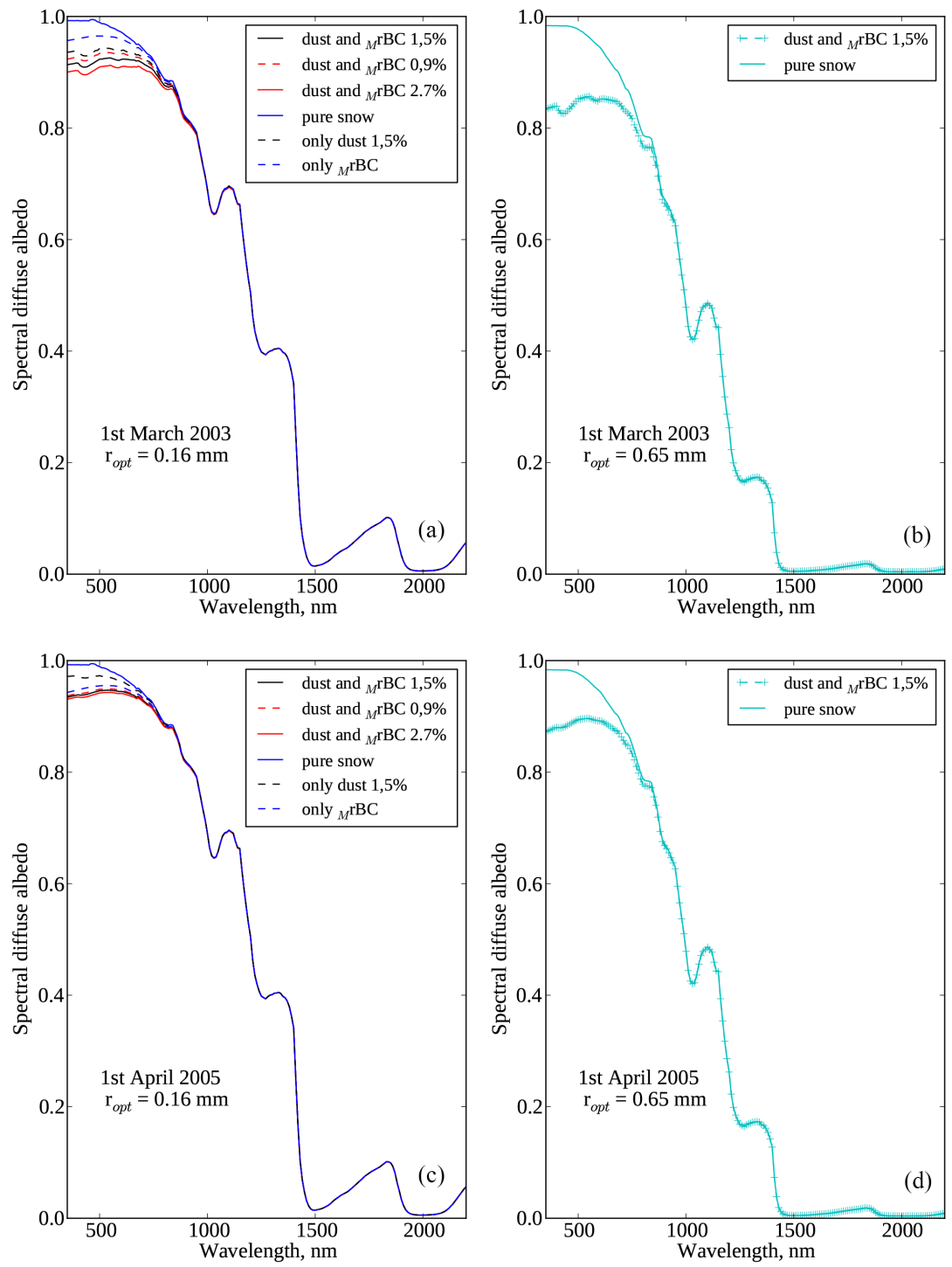

Figure 5. Simulated spectral albedo 1 March 2003 for different grain sizes, for different hematite content $(0.9,1.5$ and $2.7 \%)$, for pure snow and for different concentration and characteristics of impurities (a, b), and for the 1 April 2005 (c, d).

concentration (e.g. June 2006), the effect of $\mathrm{rBC}$ was indeed much lower that the effect of dust. Over the whole period, total impurities were responsible for a $5.6 \%$ increase in absorbed energy in the case of fine snow, with $4.4 \%$ related to dust and $1.4 \%$ to $\mathrm{BC}$, compared to pure snow. In the case of coarse snow, the impact was higher with a $10.4 \%$ increase of absorbed energy.

\subsection{Evaluation of potential melting}

The impurities deposited on the glacier surface increase the absorbed energy and can induce glacier melting under some assumption. The radiative forcing has two effects on the glacier: increasing the snow temperature for cold snow in the accumulation area, and melt the snow that reaches melt- ing temperature close to the equilibrium area. In the ablation area, the impurities load is unknown and we can't calculate the forcing. Here we only estimated a potential excess melt rate attributed to impurities deposited on snow in the glacier accumulation area or close to the equilibrium altitude, for each season (dry or monsoon) during the experimental period. The melt rate was calculated using the mean value for clear sky and cloudy sky simulations and for the average radiative forcing for coarse snow and fine snow. To represent the melt caused by the impurities on any given day, the following assumptions had to be made, (a) all other terms of the surface energy budget corresponding to turbulent fluxes and long wave net radiation remained unchanged and, (b) the snowpack was at fusion temperature. The resulting values are shown in Fig. 8. At this point, it is important to 


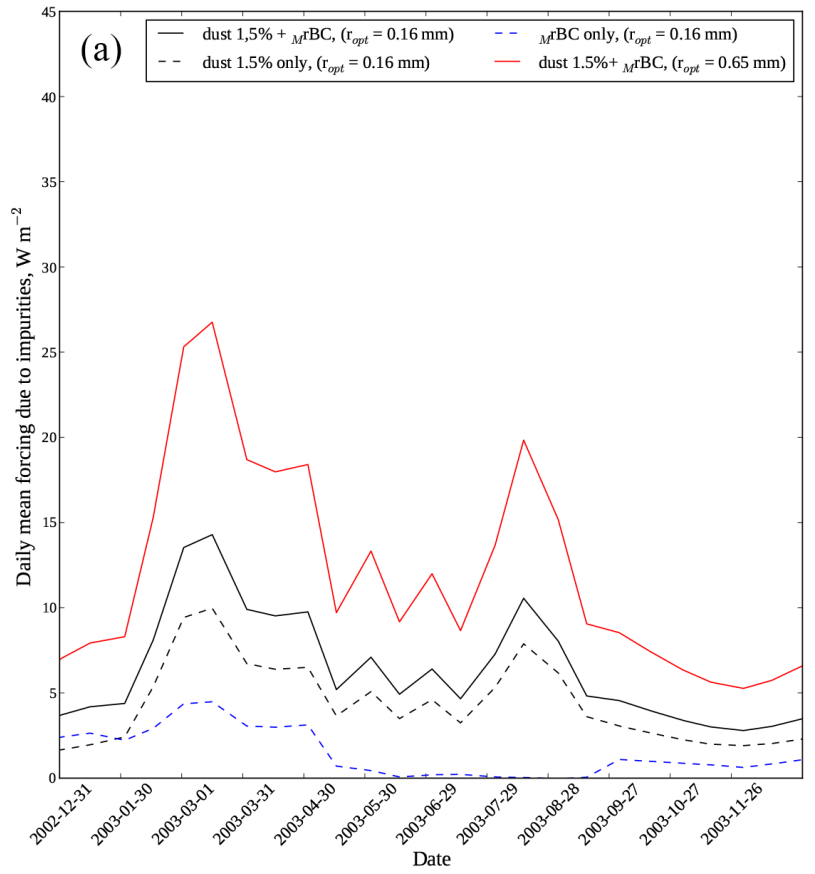

Figure 6. Daily mean forcing due to impurities under (a) clear sky (b) cloudy sky conditions in 2003 and for different combinations of impurities (dust with $1.5 \%$ hematite content) and snow grain sizes.

note that almost no melt occurs in the highest part of the glacier and at the location of the ice core drilling, because, except for some exceptional events, the firn temperature is always below melting point, as confirmed by analyses of the core that showed very limited refreezing layers. Nevertheless, this study can be considered as a theoretical approach that helps evaluate additional melt due to the presence of the same quantity of impurities in the lower part of the glacier where melt does occur in summer, as those at the drilling site. According to observations made by Kaspari et al. (2013) in the accumulation area of Mera Glacier, the deposition fluxes of $\mathrm{BC}$ and dust increase with a decrease in altitude but the gradient was not quantified. For the lower part of the ablation area, where the concentration of surface impurities is not known, our approach is limited. As in this study, we used the concentrations and fluxes reported for the high drilling site (6376 $\mathrm{m}$ a.s.1.), we are aware that the simulated melting is an approximation.

Although it is well demonstrated that the impact of dust on potential melt is much higher than the impact of $\mathrm{BC}$ on Mera Glacier, it is interesting to observe that this impact does not change much over seasons, with moderately higher values during the dry season (with higher concentrations of impurities) than during the monsoon season (Fig. 8). This is mainly due to lower solar irradiance during part of the dry season (winter) than in the summer. These results might differ if the effect of clouds is taken into account during the monsoon and may also differ as a function of aspect and shading depending on the location of the glacier.

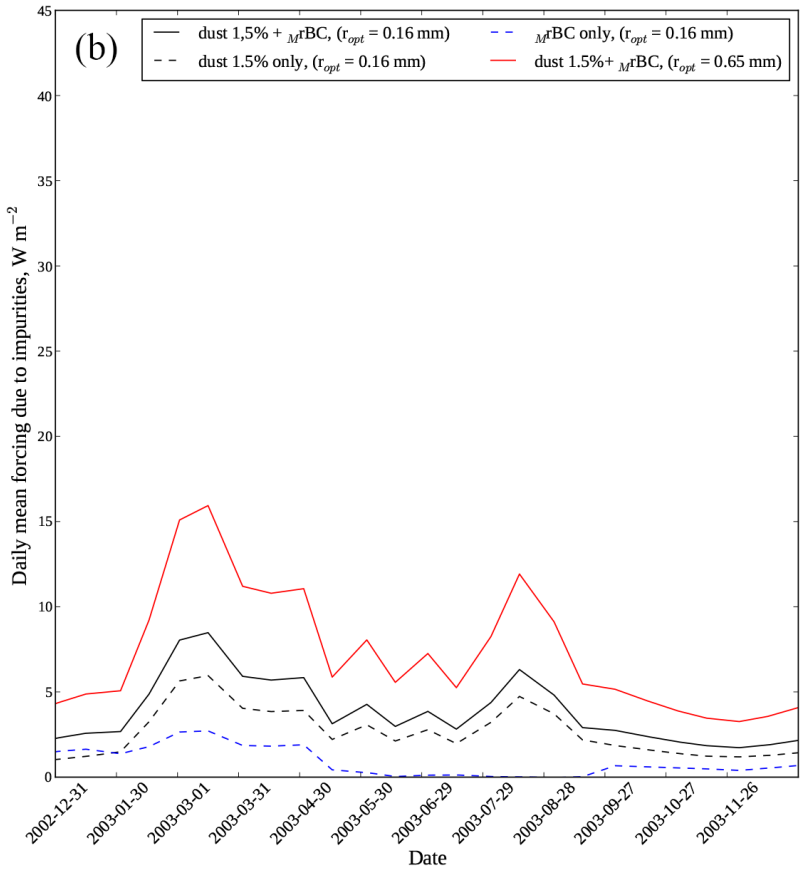

\subsection{Comparison with glacier energy and mass balance}

As is true of more than $85 \%$ of all glacierized areas in Nepal (Bajracharya et al., 2014), Mera Glacier is debris free. Dust and $\mathrm{rBC}$ particles concentrated in the surface snow increase the absorption of solar radiation, and in turn enhance melting in certain areas where surface temperatures may reach the melting point, where snowfalls are not voluminous or frequent enough to systematically cover the whole surface of the glacier, and in areas with debris, it not too dense to mask its influence. Therefore, the mid-upper part of the ablation area is usually the most affected area of a glacier, as observed in the Tien Shan Gregoriev glacier (Fujita et al., 2011). Considering that the mean ELA (Equilibrium Line Altitude) for a zero glacier-wide mass balance is at $5550 \mathrm{~m}$ a.s.l. on Mera Glacier (Wagnon et al., 2013), the area concerned is at about this elevation and represents $38 \%$ of the total area in the 5400-5700 $\mathrm{m}$ a.s.1. altitudinal range. The changes in the concentration of impurities over time (Fig. 4) are representative of the highest part of the accumulation area, where the effect is less considering that regular snowfalls during the monsoon period bury the impurities. Nevertheless, the impurities trigger additional energy transfer to the surface, and increase the temperature of the superficial layers, and very occasionally melt the snow when the surface temperature reaches $0^{\circ} \mathrm{C}$. As observed by Kaspari et al. (2013), the deposition of the impurities measured at the drilling site can be considered as the lower limit for impurity deposition of the mid-upper part of the ablation area. Consequently, our study provides 


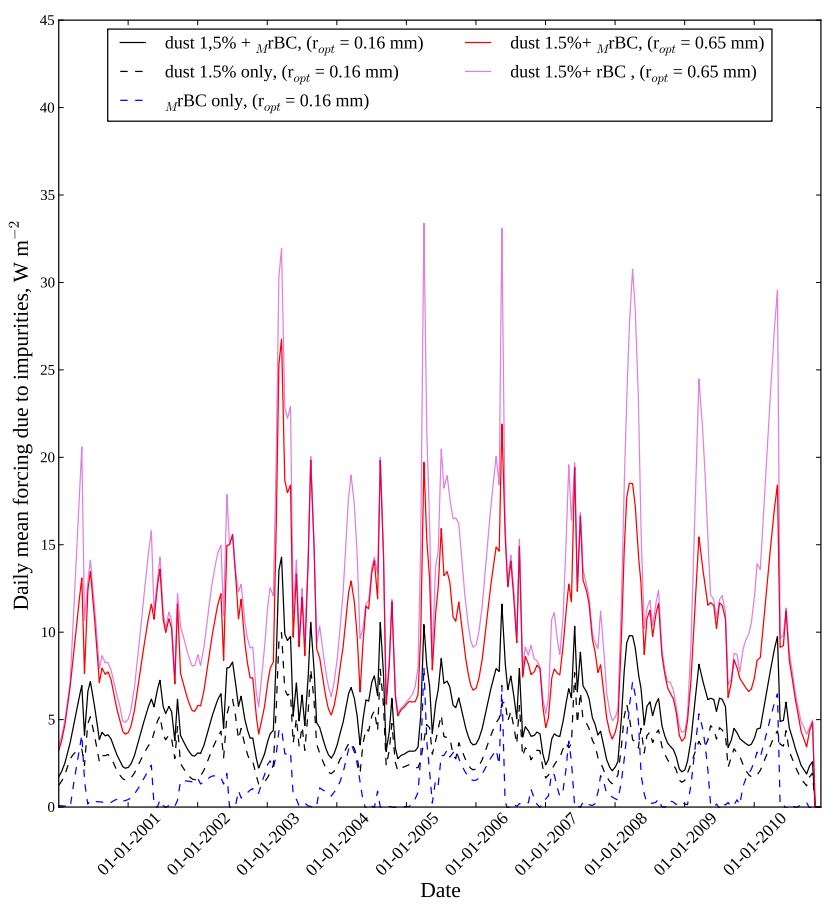

Figure 7. Daily mean radiative forcing of impurities in the clear sky simulation. The solid red and black lines represent the additional energy due to the presence of dust and $\mathrm{MrC}^{\mathrm{rBC}}$ for coarse and fine snow. The black dotted line represents dust only and the blue dotted line represents $\mathrm{MrBC}$ only for fine grain snow. The pink line represents absolute rBC concentration, dust and for coarse grain. The hematite content of dust is $1.5 \%$ in all simulations.

a theoretical quantification of the lowest expected induced melting triggered by the effect of impurities.

As illustrated in Fig. 8, the impact of impurities was estimated at an annual mean melting of $1.93 \mathrm{~kg} \mathrm{~m}^{-2} \mathrm{~d}^{-1}$ for dust and $\mathrm{rBC}\left(1.56 \mathrm{~kg} \mathrm{~m}^{-2} \mathrm{~d}^{-1}\right.$ for dust and $\mathrm{MrBC}$ ), with the fraction related to $\mathrm{rBC}$ only of $1.19 \mathrm{~kg} \mathrm{~m}^{-2} \mathrm{~d}^{-1}$ and $0.39 \mathrm{~kg} \mathrm{~m}^{-2} \mathrm{~d}^{-1}$ during the inter-monsoon and monsoon periods, respectively $\left(0.54 \mathrm{~kg} \mathrm{~m}^{-2} \mathrm{~d}^{-1}\right.$ and $0.14 \mathrm{~kg} \mathrm{~m}^{-2} \mathrm{~d}^{-1}$ respectively for $\left.{ }_{\mathrm{M}} \mathrm{rBC}\right)$. These rates correspond to $713 \mathrm{~kg} \mathrm{~m}^{-2} \mathrm{yr}^{-1}$ annual melting associated with dust and $\mathrm{rBC}$, and $342 \mathrm{~kg} \mathrm{~m}^{-2} \mathrm{yr}^{-1}$ for $\mathrm{rBC}$ alone $\left(573 \mathrm{~kg} \mathrm{~m}^{-2} \mathrm{yr}^{-1}\right.$ annual melting associated with dust and $\mathrm{M}_{\mathrm{rBC}}$, and $149 \mathrm{~kg} \mathrm{~m}^{-2} \mathrm{yr}^{-1}$ for $\mathrm{MrBC}_{\mathrm{rBlone}}$ ).

To evaluate this impact on Mera Glacier, we compared these values with the mass-balance and energy-balance measurements made on the glacier since 2007 and 2009, respectively. Using meteorological data collected on Naulek glacier by the automatic weather station (AWS) at $5360 \mathrm{~m}$ a.s.l. (Fig. 1), the surface energy balance was calculated at point scale to derive local melting and sublimation from November 2009 to October 2010, following the method of Wagnon et al. (2003). The four components of the radiative balance were measured directly in the field using a CNR1 Kipp \& Zonen sensor. The sensible and latent heat fluxes were com-

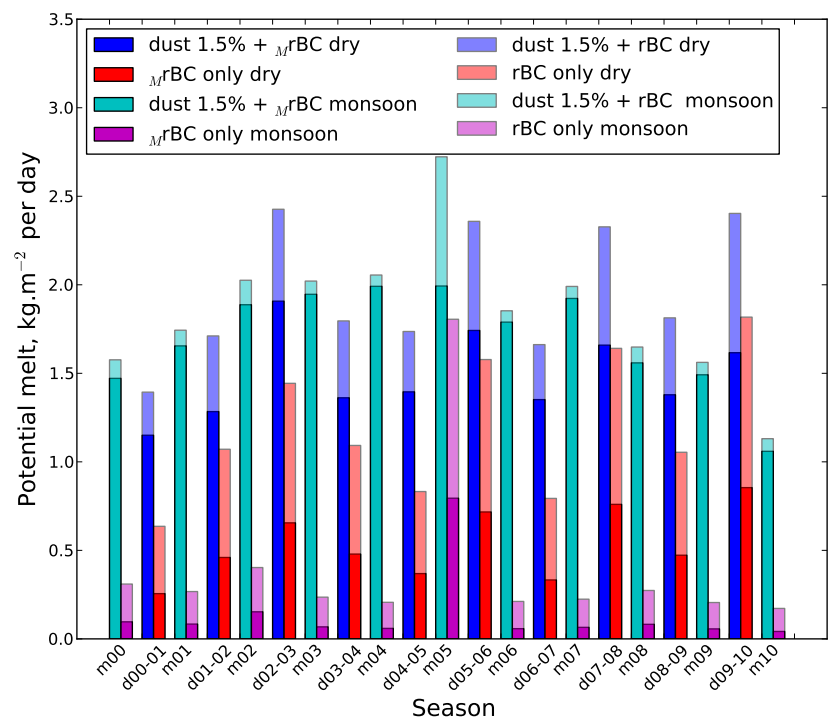

Figure 8. Potential melt per day due to the presence of impurities in the snowpack for each dry (for example d04-05 correspond to the dry season 2004-2005) and monsoon (for example m09 correspond to the monsoon 2009) season in the study. The hematite content used is $1.5 \%$. For each season, the first bar (blue or turquoise) corresponds to the presence of both dust and $\mathrm{BC}$, the second (red or pink) to BC only.

puted with the bulk aerodynamic approach including stability correction, using one level of measurements of air temperature, relative humidity and wind speed. During the melting season, the other terms of the surface energy balance (heat supplied by precipitation, and conductive heat flux inside the glacier) are negligible compared to the other fluxes. At an hourly time step, when surface temperature reaches $0^{\circ} \mathrm{C}$, the sum of the radiative and turbulent heat fluxes, when positive, gives the amount of energy available for melting. When directed away from the surface, the turbulent latent heat flux is a sublimation flux. Consequently, it was possible to compute melting and sublimation at an hourly time step. Between November 2009 and October 2010, the total annual ablation at $5360 \mathrm{~m}$ a.s.l. was $3690 \mathrm{~kg} \mathrm{~m}^{-2} \mathrm{yr}^{-1}$, including $3550 \mathrm{~kg} \mathrm{~m}^{-2} \mathrm{yr}^{-1}$ of melting and $140 \mathrm{~kg} \mathrm{~m}^{-2} \mathrm{yr}^{-1}$ of sublimation (only $4 \%$ of the annual ablation, which is thus insignificant compared to melting). Only $11 \%$ of this ablation $\left(390 \mathrm{~m} \mathrm{~kg} \mathrm{~m}^{-2}\right.$ ) occurs during the 3 months of the premonsoon season (March, April and May).

The specific mass balance is calculated annually from a stake network and topographical data derived from the Pleiades satellite image acquired in 2012 (Wagnon et al., 2013). For the year 2009-2010 at $5360 \mathrm{~m}$ a.s.l., stake readings gave an annual point-mass balance of $-2280 \mathrm{~kg} \mathrm{~m}^{-2} \mathrm{y}^{-1}$ (= accumulation - ablation). Annual accumulation is not known at $5360 \mathrm{~m}$ a.s.l., but is likely to be higher than net accumulation measured at the highest part of the glacier (6330 ma.s.l.) which undergoes only limited 
ablation through sublimation and wind erosion, and in turn collects almost all the annual snow accumulated at the glacier surface. In 2009-2010, net accumulation was $720 \mathrm{~kg} \mathrm{~m}^{-2}$ (Wagnon et al., 2013). As a consequence, annual ablation at 5,360 $\mathrm{m}$ a.s.l. would be higher than $3000 \mathrm{~kg} \mathrm{~m}^{-2} \mathrm{yr}^{-1}$ $\left(=2280+720 \mathrm{~kg} \mathrm{~m}^{-2} \mathrm{yr}^{-1}\right)$. Given that for annual ablation, sublimation is insignificant compared to melting, the true melting value would in turn be between the 3000 and $3550 \mathrm{~kg} \mathrm{~m}^{-2}$ previously obtained with the mass balance measurements and the energy balance approach respectively. Melting related to impurities calculated in this study for the same year 2009-2010 was $523 \mathrm{~kg} \mathrm{~m}^{-2} \mathrm{y}^{-1}$ annual melting for dust and $\mathrm{MrBC}_{\mathrm{rB}}$ combined, and $215 \mathrm{~kg} \mathrm{~m}^{-2} \mathrm{y}^{-1}$ for $\mathrm{MrCC}^{\mathrm{rBC}}$ alone $\left(777 \mathrm{~kg} \mathrm{~m}^{-2} \mathrm{y}^{-1}\right.$ annual melting for dust and $\mathrm{rBC}$ combined, and $468 \mathrm{~kg} \mathrm{~m}^{-2} \mathrm{y}^{-1}$ for $\mathrm{rBC}$ alone).

Comparing these values, it is clear that, with all our assumptions and considering a site where firn is close to $0{ }^{\circ} \mathrm{C}$, dust and $\mathrm{rBC}$ are responsible for a maximum of $26 \%$ of melting, while $\mathrm{rBC}$ alone accounts for a maximum of only $16 \%$ at $5360 \mathrm{~m}$ a.s.l. (17\% for dust and $\mathrm{M}_{\mathrm{rBC}}, 7 \%$ for ${ }_{\mathrm{M}} \mathrm{rBC}$ alone). Intuitive considerations for a spatial distribution extrapolated to the whole glacier would conclude on a much smaller impact of impurities on glacier melting. In addition, this study reinforces Kaspari et al. (2013) suggestion that the small fraction of land at elevations greater than $6000 \mathrm{~m}$ combined with minimal surface melt and relatively low BC and dust concentrations suggest that light absorbing impurities in the high Himalaya does not affect water resources and radiative forcing to the degree that is likely at lower elevations. The specific mass balance of Mera Glacier measured between 2007 and 2012 was $-80 \pm 280 \mathrm{~kg} \mathrm{~m}^{-2} \mathrm{yr}^{-1}$ (Wagnon et al., 2013). The impact of $\mathrm{rBC}$ on the mass balance is estimated to be in the same order than its inter-annual variability (annual standard deviation of glacier-wide mass balance of $510 \mathrm{~kg} \mathrm{~m}^{-2}$ between 2007 and 2012).

\subsection{Limits of the simulations}

The simulations presented in this section rely on a range of simplistic assumptions. These assumptions were used to circumvent certain difficulties: the exact profile of impurity content in the snowpack was not transformed into changes in surface concentrations, meteorological conditions (clouds, precipitation, etc.) were not taken into account, nor were the conditions over the whole surface of the glacier. Snow metamorphism was not taken into account either, and in the simulation, ice grains were assumed to be spherical (Libois et al., 2013). However, the results presented here were deduced from the difference between the solar radiation budget for pure snow and contaminated snow, for which these assumptions are not critical. At glacier scale, our modelling approach based on the comparison of different concentrations of impurities in the surface snow and based on theoretical considerations regarding incident solar radiation or surface conditions (melting or not) cannot provide accurate results on the effect of impurities on glacier melting, but it is still useful to roughly quantify it, at least for the debris-free ablation zone.

\section{Conclusions}

In this study, a $20 \mathrm{~m}$ firn core extracted from Mera Glacier in Nepal was used to reconstruct 10 years of aerosol deposition fluxes at $6376 \mathrm{~m}$ a.s.l. on the southern flank of the Himalayas. Some species, like water stable isotopes, rBC, ammonium or fluoride deposition are consistent with the precipitation patterns related to the monsoon, with higher or spiking concentrations during the dry season. $\mathrm{rBC}$ concentrations were compared with $\mathrm{BC}$ atmospheric measurements made at the NCO-P site. Both records agree on timing but with different concentrations in accordance with the difference in altitude between the two sites. The other proxy, dust, revealed consistently high fluxes throughout the year. The quality of these glacio-chemical profiles and the englacial temperature make this site a good candidate for environmental and climatic reconstruction based on ice core studies.

The dust and $\mathrm{rBC}$ aerosols present on the snow surface increase potential snow melting by increasing surface albedo. With this study using aerosol fluxes reconstructed from Mera Glacier firn core analyses combined with atmospheric measurements made at the Nepal Climate Observatory - Pyramid site, we estimated their impact on glacier melting. Analyses revealed that mass fluxes are a few orders of magnitude higher for dust $\left(10.4 \pm 2.8 \mathrm{~g} \mathrm{~m}^{-2} \mathrm{y}^{-1}\right)$ than for $\mathrm{rBC}\left(7.9 \pm 2.8 \mathrm{mg} \mathrm{m}^{-2} \mathrm{y}^{-1}\right)$, and that dust deposition is distributed evenly over the year but that rBC deposition is concentrated in the pre-monsoon period when valley breezes transport Atmospheric Brown Cloud pollutants that accumulate over the Himalayan foothills and North Indo-Gangetic Plains up to Himalayan glaciers. rBC concentrations and model applications appear to be more representative of regional and large scale transport, while the dust flux at Mera Glacier is probably influenced by a strong local source. When compared in terms of fluxes, the variability of the ice core signal over the 10-year period rather reflects the variability of the monsoon signal than that of emission intensity in the India+ area. According to aerosol concentrations reconstructed for the snow surface between 2000 and 2010 and using a modelling approach to calculate their impact on snow albedo and additional energy absorption, after several assumptions, we estimated the potential melting induced by these impurities. Under some assumptions that are verified around the equilibrium altitude (snow and ice around $0{ }^{\circ} \mathrm{C}$ ), the potential annual melting (mean values for 10 years) generated by combined dust and $\mathrm{rBC}$ can reach $+713 \mathrm{~kg} \mathrm{~m}^{-2} \mathrm{y}^{-1}$, or $+342 \mathrm{~kg} \mathrm{~m}^{-2} \mathrm{y}^{-1}$ for $\mathrm{rBC}$ alone. The comparison with direct mass balance measurements, which provided ablation point-mass balance values of about $3000 \mathrm{~kg} \mathrm{~m}^{-2} \mathrm{y}^{-1}$ at $5360 \mathrm{~m}$ a.s.l. for the 2009-2010 
period, and with melting derived from energy balance modelling $\left(3550 \mathrm{~kg} \mathrm{~m}^{-2} \mathrm{y}^{-1}\right)$, revealed that the estimated contribution of $\mathrm{rBC}$ alone to glacier melting is not more than $16 \%$ and that the combined contribution of dust and $\mathrm{rBC}$ to surface melting is at the most $26 \%$.

The concentrations of impurities were measured only at one point in the accumulation area, based on an ice core. An additional field campaign will provide information on the spatial variability of the surface dust and $\mathrm{rBC}$ concentrations, not only in the accumulation area as a function of aspect or elevation, but also in the ablation area, where impurities can be highly concentrated due to year-to-year melting, or washed out by running melt water.

Further investigations now need to be conducted to test the assumptions used for the simulations. Simulations using the detailed snow model Crocus (Vionnet et al., 2012) and reanalysis data for past meteorological forcing can be used to investigate the effect of snow metamorphism and local meteorological conditions. Remote sensing data such as MODIS images can be used to infer the daily radiative forcing due to impurities (Dumont et al., 2012; Painter et al., 2012) and its spatial distribution over the Mera Glacier.

\section{The Supplement related to this article is available online} at doi:10.5194/tc-8-1479-2014-supplement.

Acknowledgements. We would like to thank K. Fujita, an anonymous reviewer and interactive comments for providing useful comments and suggestions for the initial version of the manuscript. This work was supported by the French Service d'Observation GLACIOCLIM, the French National Research Agency through ANR-09-CEP-005-01/PAPRIKA, and internal LGGE funding. We thank the porters who were involved in field trips and coring operation, the Ev-K2-CNR and their Nepalese technicians for the assistance at the NCO-P.

Edited by: T. Bolch

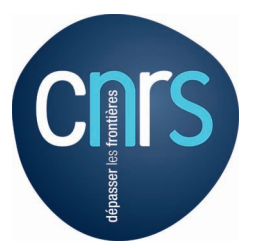

The publication of this article is financed by CNRS-INSU.

\section{References}

Araguás-Araguás, L., Froehlich, K., and Rozanski, K.: Stable isotope composition of precipitation over southeast Asia, J. Geophys. Res., 103, 28721-28742, doi:10.1029/98jd02582, 1998.

Bajracharya, S. R., Maharjan, S. B., and Shresta, F.: The status and decadal change of glaciers in Bhutan from the 1980s to 2010 based on satellite data, Ann. Glaciol., 55, 159-166, 2014.
Balkanski, Y., Schulz, M., Claquin, T., and Guibert, S.: Reevaluation of Mineral aerosol radiative forcings suggests a better agreement with satellite and AERONET data, Atmos. Chem. Phys., 7, 81-95, doi:10.5194/acp-7-81-2007, 2007.

Barros, A. P. and Lang, T. J.: Monitoring the Monsoon in the Himalayas: Observations in Central Nepal, June 2001, Mon. Weather Rev., 131, 1408-1427, doi:10.1175/15200493(2003)131<1408:mtmith>2.0.co;2, 2003.

Bonasoni, P., Laj, P., Marinoni, A., Sprenger, M., Angelini, F., Arduini, J., Bonafè, U., Calzolari, F., Colombo, T., Decesari, S., Di Biagio, C., di Sarra, A. G., Evangelisti, F., Duchi, R., Facchini, MC., Fuzzi, S., Gobbi, G. P., Maione, M., Panday, A., Roccato, F., Sellegri, K., Venzac, H., Verza, GP., Villani, P., Vuillermoz, E., and Cristofanelli, P.: Atmospheric Brown Clouds in the Himalayas: first two years of continuous observations at the Nepal Climate Observatory-Pyramid (5079 m), Atmos. Chem. Phys., 10, 7515-7531, doi:10.5194/acp-10-7515-2010, 2010.

Bond, T. C., Bhardwaj, E., Dong, R., Jogani, R., Jung, S., Roden, C., Streets, D. G., and Trautmann, N. M.: Historical emissions of black and organic carbon aerosol from energy-related combustion, 1850-2000, Global Biogeochem. Cy., 21, GB2018, doi:10.1029/2006gb002840, 2007.

Bond, T. C., Doherty, S. J., Fahey, D. W., Forster, P. M., Berntsen, T., DeAngelo, B. J., Flanner, M. G., Ghan, S., Kärcher, B., Koch, D., Kinne, S., Kondo, Y., Quinn, P. K., Sarofim, M. C., Schultz, M. G., Schulz, M., Venkataraman, C., Zhang, H., Zhang, S., Bellouin, N., Guttikunda, S. K., Hopke, P. K., Jacobson, M. Z., Kaiser, J. W., Klimont, Z., Lohmann, U., Schwarz, J. P., Shindell, D., Storelvmo, T., Warren, S. G., and Zender, C. S.: Bounding the role of black carbon in the climate system: A scientific assessment, J. Geophys. Res.-Atmos., 118, 5380-5552, doi:10.1002/jgrd.50171, 2013.

Bookhagen, B. and Burbank, D. W.: Topography, relief, and TRMM-derived rainfall variations along the Himalaya, Geophys. Res. Lett., 33, L08405, doi:10.1029/2006g1026037, 2006.

Carrico, C. M., Bergin, M. H., Shrestha, A. B., Dibb, J. E., Gomes, L., and Harris, J. M.: The importance of carbon and mineral dust to seasonal aerosol properties in the Nepal Himalaya, Atmos. Environ., 37, 2811-2824, doi:10.1016/S1352-2310(03)00197-3, 2003.

Cristofanelli, P., Bracci, A., Sprenger, M., Marinoni, A., Bonafè, U., Calzolari, F., Duchi, R., Laj, P., Pichon, J. M., Roccato, F., Venzac, H., Vuillermoz, E., and Bonasoni, P.: Tropospheric ozone variations at the Nepal Climate ObservatoryPyramid (Himalayas, $5079 \mathrm{~m}$ a.s.l.) and influence of deep stratospheric intrusion events, Atmos. Chem. Phys., 10, 6537-6549, doi:10.5194/acp-10-6537-2010, 2010.

Cross, E. S., Onasch, T. B., Ahern, A., Wrobel, W., Slowik, J. G., Olfert, J., Lack, D. A., Massoli, P., Cappa, C. D., Schwarz, J. P., Spackman, J. R., Fahey, D. W., Sedlacek, A., Trimborn, A., Jayne, J. T., Freedman, A., Williams, L. R., Ng, N. L., Mazzoleni, C., Dubey, M., Brem, B., Kok, G., Subramanian, R., Freitag, S., Clarke, A., Thornhill, D., Marr, L. C., Kolb, C. E., Worsnop, D. R., and Davidovits, P.: Soot Particle Studies "Instrument InterComparison" Project Overview, Aerosol Sci. Tech., 44, 592-611, doi:10.1080/02786826.2010.482113, 2010.

Decesari, S., Facchini, M. C., Carbone, C., Giulianelli, L., Rinaldi, M., Finessi, E., Fuzzi, S., Marinoni, A., Cristofanelli, P., Duchi, R., Bonasoni, P., Vuillermoz, E., Cozic, J., Jaffrezo, J. L., and 
Laj, P.: Chemical composition of $\mathrm{PM}_{10}$ and $\mathrm{PM}_{1}$ at the highaltitude Himalayan station Nepal Climate Observatory-Pyramid (NCO-P) (5079 m a.s.1.), Atmos. Chem. Phys., 10, 4583-4596, doi:10.5194/acp-10-4583-2010, 2010.

Delmonte, B., Petit, J., and Maggi, V.: Glacial to Holocene implications of the new 27000-year dust record from the EPICA Dome C (East Antarctica) ice core, Clim. Dynam., 18, 647-660, doi:10.1007/s00382-001-0193-9, 2002.

Diehl, T., Heil, A., Chin, M., Pan, X., Streets, D., Schultz, M., and Kinne, S.: Anthropogenic, biomass burning, and volcanic emissions of black carbon, organic carbon, and SO2 from 1980 to 2010 for hindcast model experiments, Atmos. Chem. Phys. Discuss., 12, 24895-24954, doi:10.5194/acpd-12-24895-2012, 2012.

Dumont, M., Gardelle, J., Sirguey, P., Guillot, A., Six, D., Rabatel, A., and Arnaud, Y.: Linking glacier annual mass balance and glacier albedo retrieved from MODIS data, The Cryosphere, 6, 1527-1539, doi:10.5194/tc-6-1527-2012, 2012.

Flanner, M. G., Liu, X., Zhou, C., Penner, J. E., and Jiao, C.: Enhanced solar energy absorption by internally-mixed black carbon in snow grains, Atmos. Chem. Phys., 12, 4699-4721, doi:10.5194/acp-12-4699-2012, 2012.

Fowler, D., Pilegaard, K., Sutton, M. A., Ambus, P., Raivonen, M., Duyzer, J., Simpson, D., Fagerli, H., Fuzzi, S., Schjoerring, J. K., Granier, C., Neftel, A., Isaksen, I. S. A., Laj, P., Maione, M., Monks, P. S., Burkhardt, J., Daemmgen, U., Neirynck, J., Personne, E., Wichink-Kruit, R., Butterbach-Bahl, K., Flechard, C., Tuovinen, J. P., Coyle, M., Gerosa, G., Loubet, B., Altimir, N., Gruenhage, L., Ammann, C., Cieslik, S., Paoletti, E., Mikkelsen, T. N., Ro-Poulsen, H., Cellier, P., Cape, J. N., Horvajth, L., Loreto, F., Niinemets, Ã., Palmer, P. I., Rinne, J., Misztal, P., Nemitz, E., Nilsson, D., Pryor, S., Gallagher, M. W., Vesala, T., Skiba, U., Bruggemann, N., Zechmeister-Boltenstern, S., Williams, J., O'Dowd, C., Facchini, M. C., de Leeuw, G., Flossman, A., Chaumerliac, N., and Erisman, J. W.: Atmospheric composition change: Ecosystems - Atmosphere interactions, Atmos. Environ., 43, 5193-5267, doi:10.1016/j.atmosenv.2009.07.068, 2009.

Fujita, K., Takeuchi, N., Nikitin, S. A., Surazakov, A. B., Okamoto, S., Aizen, V. B., and Kubota, J.: Favorable climatic regime for maintaining the present-day geometry of the Gregoriev Glacier, Inner Tien Shan, The Cryosphere, 5, 539-549, doi:10.5194/tc-5539-2011, 2011.

Gautam, R., Hsu, N. C., Lau, W. K. M., and Yasunari, T. J.: Satellite observations of desert dust-induced Himalayan snow darkening, Geophys. Res. Lett., 40, 988-993, doi:10.1002/grl.50226, 2013.

Ginot, P., Kull, C., Schwikowski, M., Schotterer, U., and Gäggeler, H. W.: Effects of post-depositional processes on snow composition of a subtropical glacier (Cerro Tapado, Chilean Andes), J. Geophys. Res., 106, 32375-32386, 2001.

Ginot, P., Stampfli, F., Stampfli, D., Schwikowski, M., and Gäggeler, H. W.: FELICS, a new ice core drilling system for high-altitude glaciers, Fifth International Workshop on Ice Drilling Technology, Special Issue 56, 38-48, 2002.

Gobbi, G. P., Angelini, F., Bonasoni, P., Verza, G. P., Marinoni, A., and Barnaba, F.: Sunphotometry of the 2006-2007 aerosol optical/radiative properties at the Himalayan Nepal Climate Observatory-Pyramid (5079 m a.s.1.), Atmos. Chem. Phys., 10, 11209-11221, doi:10.5194/acp-10-11209-2010, 2010.
Granier, C., Bessagnet, B., Bond, T., D’ Angiola, A., Denier van der Gon, H., Frost, G. J., Heil, A., Kaiser, J. W., Kinne, S., Klimont, Z., Kloster, S., Lamarque, J.-F., Liousse, C., Masui, T., Meleux, F., Mieville, A., Ohara, T., Raut, J.-C., Riahi, K., Schultz, M. G., Smith, S. J., Thompson, A., Aardenne, J., Werf, G. R., and Vuuren, D. P.: Evolution of anthropogenic and biomass burning emissions of air pollutants at global and regional scales during the 1980-2010 period, Clim. Change, 109, 163-190, doi:10.1007/s10584-011-0154-1, 2011.

Hindman, E. E. and Upadhyay, B. P.: Air pollution transport in the Himalayas of Nepal and Tibet during the 1995-1996 dry season, Atmos. Environ., 36, 727-739, 2002.

International Atomic Energy Agency/World Meteorological Organization, I. W.: Global Network of Isotopes in Precipitation: The GNIP Database, Vienna, Austria, 2006.

Isaksen, I. S. A., Granier, C., Myhre, G., Berntsen, T. K., Dalsøren, S. B., Gauss, M., Klimont, Z., Benestad, R., Bousquet, P., Collins, W., Cox, T., Eyring, V., Fowler, D., Fuzzi, S., Jackel, P., Laj, P., Lohmann, U., Maione, M., Monks, P., Prevot, A. S. H., Raes, F., Richter, A., Rognerud, B., Schulz, M., Shindell, D., Stevenson, D. S., Storelvmo, T., Wang, W. C., van Weele, M., Wild, M., and Wuebbles, D.: Atmospheric composition change: Climate - Chemistry interactions, Atmos. Environ., 43, 51385192, doi:10.1016/j.atmosenv.2009.08.003, 2009.

Jenkins, M., Kaspari, S., Kang, S., Grigholm, B., and Mayewski, P. A.: Black carbon concentrations from a Tibetan Plateau ice core spanning 1843-1982: recent increases due to emissions and glacier melt, The Cryosphere Discuss., 7, 4855-4880, doi:10.5194/tcd-7-4855-2013, 2013.

Kang, S., Mayewski, P. A., Qin, D., Yan, Y., Hou, S., Zhang, D., Ren, J., and Kreutz, K.: Glaciochemical records from a Mt. Everest ice core: relationship to atmospheric circulation over Asia, Atmos. Environ., 36, 3351-3361, 2002.

Kaspari, S., Mayewski, P. A., Handley, M., Osterberg, E., Kang, S., Sneed, S., Hou, S., and Qin, D.: Recent increases in atmospheric concentrations of Bi, U, Cs, S and Ca from a 350-year Mount Everest ice core record, J. Geophys. Res.-Atmos., 114, D04302, doi:10.1029/2008jd011088, 2009.

Kaspari, S., Painter, T. H., Gysel, M., and Schwikowski, M.: Seasonal and elevational variations of black carbon and dust in snow and ice in the Solu-Khumbu, Nepal and estimated radiative forcings, Atmos. Chem. Phys. Discuss., 13, 33491-33521, doi:10.5194/acpd-13-33491-2013, 2013.

Kaspari, S. D., Schwikowski, M., Gysel, M., Flanner, M. G., Kang, S., Hou, S., and Mayewski, P. A.: Recent increase in black carbon concentrations from a Mt. Everest ice core spanning 1860-2000 AD, Geophys. Res. Lett., 38, L04703, doi:10.1029/2010g1046096, 2011.

Lamarque, J.-F., Bond, T. C., Eyring, V., Granier, C., Heil, A., Klimont, Z., Lee, D., Liousse, C., Mieville, A., Owen, B., Schultz, M. G., Shindell, D., Smith, S. J., Stehfest, E., Van Aardenne, J., Cooper, O. R., Kainuma, M., Mahowald, N., McConnell, J. R., Naik, V., Riahi, K., and van Vuuren, D. P.: Historical (1850-2000) gridded anthropogenic and biomass burning emissions of reactive gases and aerosols: methodology and application, Atmos. Chem. Phys., 10, 7017-7039, doi:10.5194/acp10-7017-2010, 2010.

Lee, K., Hur, S. D., Hou, S., Burn-Nunes, L. J., Hong, S., Barbante, C., Boutron, C. F., and Rosman, K. J. R.: Isotopic signatures 
for natural versus anthropogenic $\mathrm{Pb}$ in high-altitude Mt. Everest ice cores during the past 800 years, Sci. Total Environ., 412413, 194-202, http://dx.doi.org/10.1016/j.scitotenv.2011.10.002, 2011.

Libois, Q., Picard, G., France, J. L., Arnaud, L., Dumont, M., Carmagnola, C. M., and King, M. D.: Influence of grain shape on light penetration in snow, The Cryosphere, 7, 1803-1818, doi:10.5194/tc-7-1803-2013, 2013.

Lim, S., Faïn, X., Zanatta, M., Cozic, J., Jaffrezo, J.-L., Ginot, P., and Laj, P.: Refractory black carbon mass concentrations in snow and ice: method evaluation and inter-comparison with elemental carbon measurement, Atmos. Meas. Tech. Discuss., 7, 35493589, doi:10.5194/amtd-7-3549-2014, 2014.

Lu, Z., Zhang, Q., and Streets, D. G.: Sulfur dioxide and primary carbonaceous aerosol emissions in China and India, 1996-2010, Atmos. Chem. Phys., 11, 9839-9864, doi:10.5194/acp-11-98392011, 2011.

Marcq, S., Laj, P., Roger, J. C., Villani, P., Sellegri, K., Bonasoni, P., Marinoni, A., Cristofanelli, P., Verza, G. P., and Bergin, M.: Aerosol optical properties and radiative forcing in the high Himalaya based on measurements at the Nepal Climate Observatory-Pyramid site (5079 m a.s.1.), Atmos. Chem. Phys., 10, 5859-5872, doi:10.5194/acp-10-5859-2010, 2010.

Marinoni, A., Polesello, S., Smiraglia, C., and Valsecchi, S.: Chemical composition of freshsnow samples from the southern slope of Mt. Everest region (Khumbu-Himal region, Nepal), Atmos. Environ., 35, 3183-3190, 2001.

Marinoni, A., Cristofanelli, P., Laj, P., Duchi, R., Calzolari, F., Decesari, S., Sellegri, K., Vuillermoz, E., Verza, G. P., Villani, P., and Bonasoni, P.: Aerosol mass and black carbon concentrations, a two year record at NCO-P (5079 m, Southern Himalayas), Atmos. Chem. Phys., 10, 8551-8562, doi:10.5194/acp-10-85512010, 2010.

Ménégoz, M., Krinner, G., Balkanski, Y., Boucher, O., Cozic, A., Lim, S., Ginot, P., Laj, P., Gallée, H., Wagnon, P., Marinoni, A., and Jacobi, H. W.: Snow cover sensitivity to black carbon deposition in the Himalayas: from atmospheric and ice core measurements to regional climate simulations, Atmos. Chem. Phys., 14, 4237-4249, doi:10.5194/acp-14-4237-2014, 2014.

Menon, S., Koch, D., Beig, G., Sahu, S., Fasullo, J., and Orlikowski, D.: Black carbon aerosols and the third polar ice cap, Atmos. Chem. Phys., 10, 4559-4571, doi:10.5194/acp-10-4559-2010, 2010.

Ming, J., Zhang, D., Kang, S., and Tian, W.: Aerosol and fresh snow chemistry in the East Rongbuk Glacier on the northern slope of Mt. Qomolangma (Everest), J. Geophys. Res., 112, D15307, doi:10.1029/2007jd008618, 2007.

Ming, J., Cachier, H., Xiao, C., Qin, D., Kang, S., Hou, S., and $\mathrm{Xu}$, J.: Black carbon record based on a shallow Himalayan ice core and its climatic implications, Atmos. Chem. Phys., 8, 13431352, doi:10.5194/acp-8-1343-2008, 2008.

Ming, J., Xiao, C., Cachier, H., Qin, D., Qin, X., Li, Z., and Pu, J.: Black Carbon (BC) in the snow of glaciers in west China and its potential effects on albedos, Atmos. Res., 92, 114-123, 2009.

Moteki, N. and Kondo, Y.: Effects of Mixing State on Black Carbon Measurements by Laser-Induced Incandescence, Aerosol Sci. Tech., 41, 398-417, doi:10.1080/02786820701199728, 2007.

Moteki, N. and Kondo, Y.: Dependence of Laser-Induced Incandescence on Physical Properties of Black Carbon Aerosols: Mea- surements and Theoretical Interpretation, Aerosol Sci. Tech., 44, 663-675, doi:10.1080/02786826.2010.484450, 2010.

Nair, V. S., Babu, S. S., Moorthy, K. K., Sharma, A. K., Marinoni, A., and Ajai: Black carbon aerosols over the Himalayas: direct and surface albedo forcing, Tellus B, 65, doi:10.3402/tellusb.v65i0.19738, 2013.

Painter, T. H., Bryant, A. C., and Skiles, S. M.: Radiative forcing by light absorbing impurities in snow from MODIS surface reflectance data, Geophys. Res. Lett., 39, L17502, doi:10.1029/2012g1052457, 2012.

Petzold, A. and Schönlinner, M.: Multi-angle absorption photometry-a new method for the measurement of aerosol light absorption and atmospheric black carbon, J. Aerosol Sci., 35, 421-441, doi:10.1016/j.jaerosci.2003.09.005, 2004.

Petzold, A., Ogren, J. A., Fiebig, M., Laj, P., Li, S.-M., Baltensperger, U., Holzer-Popp, T., Kinne, S., Pappalardo, G., Sugimoto, N., Wehrli, C., Wiedensohler, A., and Zhang, X.-Y.: Recommendations for reporting "black carbon" measurements, Atmos. Chem. Phys., 13, 8365-8379, doi:10.5194/acp-13-83652013, 2013.

Prasad, A. K. and Singh, R. P.: Changes in aerosol parameters during major dust storm events (2001-2005) over the Indo-Gangetic Plains using AERONET and MODIS data, J. Geophys. Res.Atmos., 112, D09208, doi:10.1029/2006jd007778, 2007.

Preunkert, S. and Legrand, M.: Towards a quasi-complete reconstruction of past atmospheric aerosol load and composition (organic and inorganic) over Europe since 1920 inferred from Alpine ice cores, Clim. Past, 9, 1403-1416, doi:10.5194/cp-91403-2013, 2013.

Ricchiazzi, P., Yang, S., Gautier, C., and Sowle, D.: SBDART: A Research and Teaching Software Tool for Plane-Parallel Radiative Transfer in the Earth's Atmosphere, B. Am. Meteorol. Soc., 79, 2101-2114, 1998.

Schwarz, J. P., Gao, R. S., Fahey, D. W., Thomson, D. S., Watts, L. A., Wilson, J. C., Reeves, J. M., Darbeheshti, M., Baumgardner, D. G., Kok, G. L., Chung, S. H., Schulz, M., Hendricks, J., Lauer, A., Kärcher, B., Slowik, J. G., Rosenlof, K. H., Thompson, T. L., Langford, A. O., Loewenstein, M., and Aikin, K. C.: Single-particle measurements of midlatitude black carbon and light-scattering aerosols from the boundary layer to the lower stratosphere, J. Geophys. Res.-Atmos., 111, D16207, doi:10.1029/2006jd007076, 2006.

Sellegri, K., Laj, P., Venzac, H., Boulon, J., Picard, D., Villani, P., Bonasoni, P., Marinoni, A., Cristofanelli, P., and Vuillermoz, E.: Seasonal variations of aerosol size distributions based on longterm measurements at the high altitude Himalayan site of Nepal Climate Observatory-Pyramid (5079 m), Nepal, Atmos. Chem. Phys., 10, 10679-10690, doi:10.5194/acp-10-10679-2010, 2010.

Shrestha, A. B., Wake, C. P., Dibb, J. E., and Whitlow, S. I.: Aerosol and Precipitation Chemistry at a Remote Himalayan Site in Nepal, Aerosol Sci. Tech., 36, 441-456, 2002.

Stamnes, K., Tsay, S. C., Wiscombe, W., and Jayaweera, K.: Numerically stable algorithm for discrete-ordinate-method radiative transfer in multiple scattering and emitting layered media, Appl. Optics, 27, 2502-2509, 1988.

Sterle, K. M., McConnell, J. R., Dozier, J., Edwards, R., and Flanner, M. G.: Retention and radiative forcing of black carbon in eastern Sierra Nevada snow, The Cryosphere, 7, 365-374, doi:10.5194/tc-7-365-2013, 2013. 
Sun, J., Qin, D., Mayewski, P. A., Dibb, J. E., Whitlow, S., Li, Z., and Yang, Q.: Soluble species in aerosol and snow and their relationship at Glacier 1, Tien Shan, China, J. Geophys. Res.-Atmos., 103, 20021-20028, 1998.

Thompson, L. G., Mosley-Thompson, E., Davis, M. E., Bolzan, J. F., Dai, J., Klein, L., Yao, T., Wu, X., Xie, Z., and Gundestrup, N.: Holocene - Late Pleistocene Climatic Ice Core Records from Qinghai-Tibetan Plateau, Science, 246, 474-477, doi:10.1126/science.246.4929.474, 1989.

Thompson, L. G., Mosley-Thompson, E., Davis, M. E., Bolzan, J. F., Dai, J., and Klein, L.: Glacial stage ice core records from the subtropical Dunde ice cap, China, Ann. Glaciol., 14, 288-297, 1990.

Thompson, L. G., Yao, T., Mosley-Thompson, E., Davis, M. E., Henderson, K. A., and Lin, P. N.: A high-resolution millenial record of the South Asian monsoon from Himalayan ice cores, Science, 289, 1916-1919, 2000.

Ueno, K., Toyotsu, K., Bertolani, L., and Tartari, G.: Stepwise Onset of Monsoon Weather Observed in the Nepal Himalaya, Mon. Weather Rev., 136, 2507-2522, doi:10.1175/2007mwr2298.1, 2008.

van der Werf, G. R., Randerson, J. T., Giglio, L., Collatz, G. J., Kasibhatla, P. S., and Arellano Jr., A. F.: Interannual variability in global biomass burning emissions from 1997 to 2004, Atmos. Chem. Phys., 6, 3423-3441, doi:10.5194/acp-6-3423-2006, 2006.

Vionnet, V., Brun, E., Morin, S., Boone, A., Faroux, S., Le Moigne, P., Martin, E., and Willemet, J.-M.: The detailed snowpack scheme Crocus and its implementation in SURFEX v7.2, Geosci. Model Dev., 5, 773-791, doi:10.5194/gmd-5-773-2012, 2012.

Vuille, M., Werner, M., Bradley, R. S., and Keimig, F.: Stable isotopes in precipitation in the Asian monsoon region, J. Geophys. Res., 110, D23108, doi:10.1029/2005jd006022, 2005.

Wagnon, P., Vincent, C., Arnaud, Y., Berthier, E., Vuillermoz, E., Gruber, S., Ménégoz, M., Gilbert, A., Dumont, M., Shea, J. M., Stumm, D., and Pokhrel, B. K.: Seasonal and annual mass balances of Mera and Pokalde glaciers (Nepal Himalaya) since 2007, The Cryosphere, 7, 1769-1786, doi:10.5194/tc-7-17692013, 2013.

Warren, S. G. and Wiscombe, W. J.: A Model for the Spectral Albedo of Snow. II: Snow Containing Atmospheric Aerosols, J. Atmos. Sci., 37, 2734-2745, 1980.
Warren, S. G. and Brandt, R. E.: Optical constants of ice from the ultraviolet to the microwave: A revised compilation, J. Geophys. Res. Atmos., 113, D14220, doi:10.1029/2007jd009744, 2008.

Xu, B., Cao, J., Hansen, J., Yao, T., Joswia, D. R., Wang, N., Wu, G., Wang, M., Zhao, H., Yang, W., Liu, X., and He, J.: Black soot and the survival of Tibetan glaciers, P. Natl. Acad. Sci. USA, 106, 22114-22118, doi:10.1073/pnas.0910444106, 2009.

Xu, B., Cao, J., Joswiak, D., R., Liu, X., Zhao, H., and He, J.: Postdepositional enrichment of black soot in snow-pack and accelerated melting of Tibetan glaciers, Environ. Res. Lett., 7, 014022, doi:10.1088/1748-9326/7/1/014022, 2012.

Xu, J., Hou, S., Qin, D., Kaspari, S., Mayewski, P. A., Petit, J.R., Delmonte, B., Kang, S., Ren, J., Chappellaz, J., and Hong, S.: A 108.83-m ice-core record of atmospheric dust deposition at Mt. Qomolangma (Everest), Central Himalaya, Quatern. Res., 73, 33-38, 2010.

Yasunari, T. J., Bonasoni, P., Laj, P., Fujita, K., Vuillermoz, E., Marinoni, A., Cristofanelli, P., Duchi, R., Tartari, G., and Lau, K.-M.: Estimated impact of black carbon deposition during premonsoon season from Nepal Climate Observatory - Pyramid data and snow albedo changes over Himalayan glaciers, Atmos. Chem. Phys., 10, 6603-6615, doi:10.5194/acp-10-6603-2010, 2010.

Yasunari, T. J., Tan, Q., Lau, K. M., Bonasoni, P., Marinoni, A., Laj, P., Ménégoz, M., Takemura, T., and Chin, M.: Estimated range of black carbon dry deposition and the related snow albedo reduction over Himalayan glaciers during dry pre-monsoon periods, Atmos. Environ., 78, 259-267, doi:10.1016/j.atmosenv.2012.03.031, 2013.

Zhang, Q., Kang, S., Kaspari, S., Li, C., Qin, D., Mayewski, P. A., and Hou, S.: Rare earth elements in an ice core from Mt. Everest: Seasonal variations and potential sources, Atmos. Res., 94, 300312, 2009.

Zhang, X., Masayoshi, N., Fujita, K., Yao, T., and Han, J.: Variation of precipitation $\delta^{18} \mathrm{O}$ in Langtang Valley Himalayas, Sci. China Ser. D, 44, 769-778, doi:10.1007/bf02907089, 2001.

Zheng, M. and Liu, X.: Hydrochemistry of Salt Lakes of the Qinghai-Tibet Plateau, China, Aquat. Geochem., 15, 293-320, doi:10.1007/s10498-008-9055-y, 2009. 